
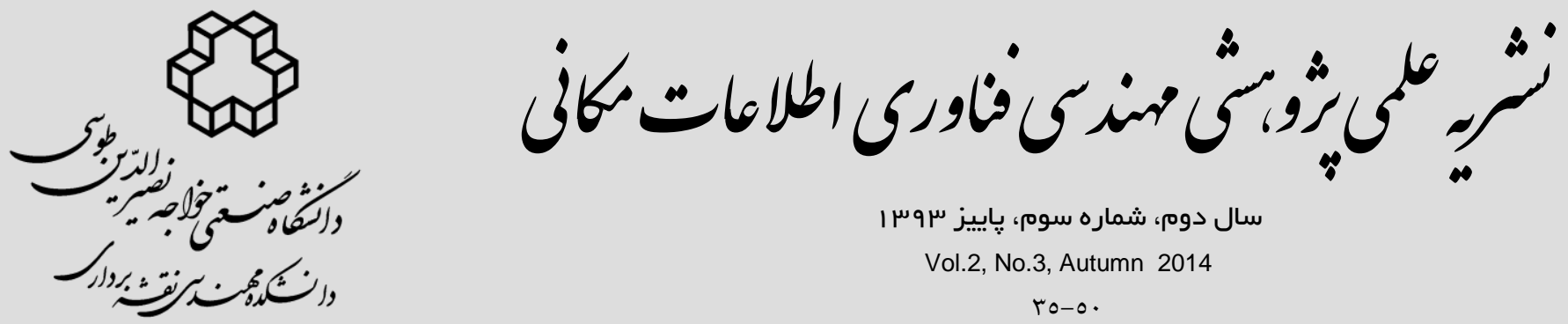

سال دوم، شماره سوم، ياييز سوسر

Vol.2, No.3, Autumn 2014

ro-o.

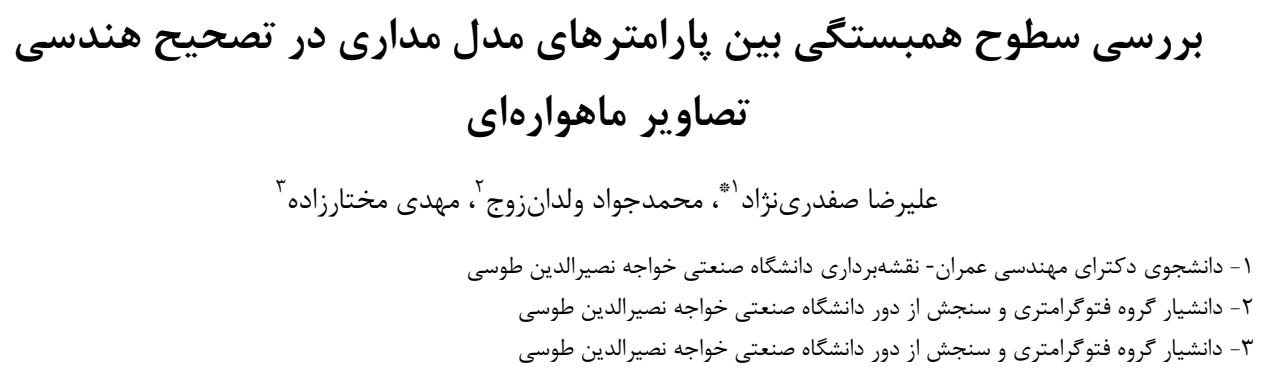

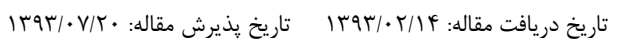

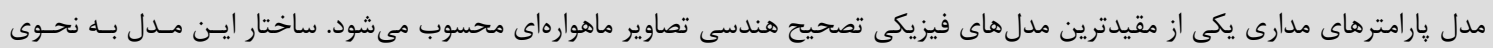

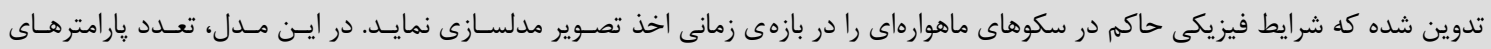

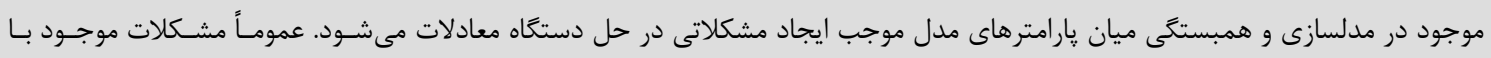

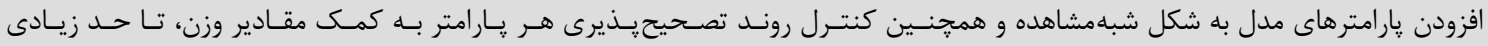

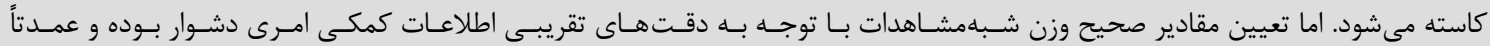

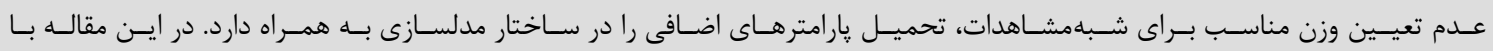

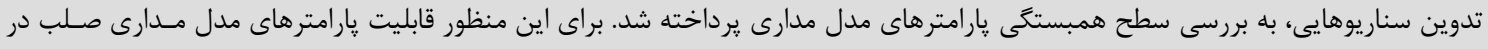

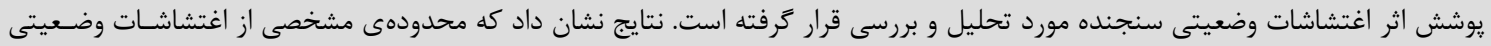

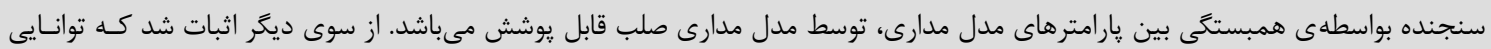

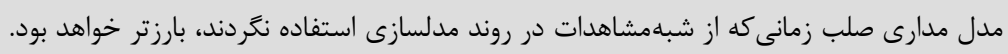

وازههاى كليدى: مدل بارامترهاى مدارى، همبستكى، تقاطع فضاى، شرطهمخطى، يارامترهاى كيلرى، تصاوير ماهوارهاى، تصحيح هندسى.

* نويسنده مكاتبه كننده: عليرضا صفدرىنزاد، آدرس: دانشكدهى زئودزى و زئوماتيك دانشًاه صنعتى خواجه نصيرالدين طوسى ،

Email: Safdari_Nezhad@sina.kntu.ac.ir

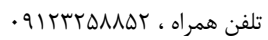


بر مكان هندسى يك بيضى داشته و وضـعيت لحظـــاى

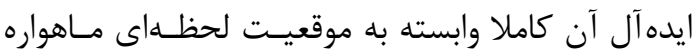

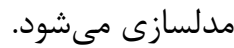

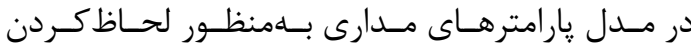

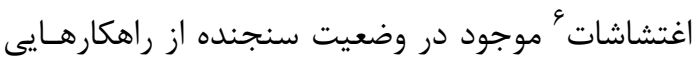

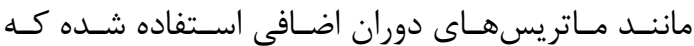
بدون تاثيركذارى بر موقعيت سنجنده، تنها اغتشاشـات

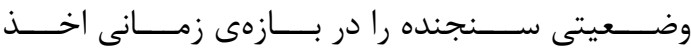
تصوير مدلسازى مى كنند [9]. اما وجود همبستخى بـانلا بين يارامترهـاى مــدل غنـى شـــه توسـط پِارامترهـاى

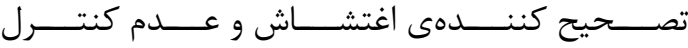

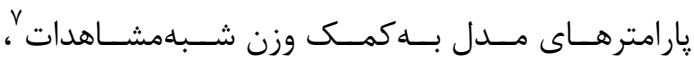

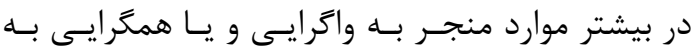

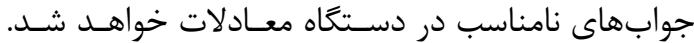

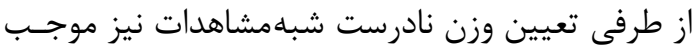

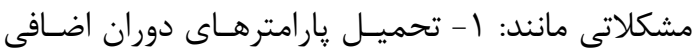

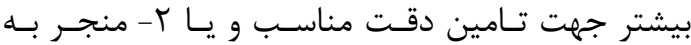

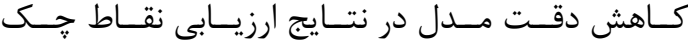
خواهدشد.

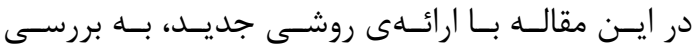

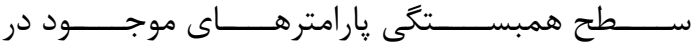

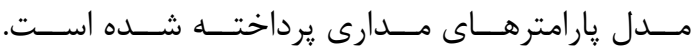
ضــرورت ايــن بررســى را مـى تـــوان در شناســايى و و

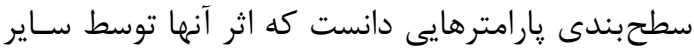

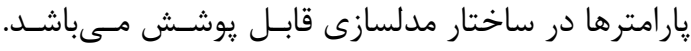

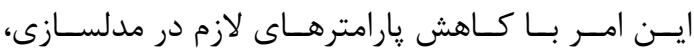

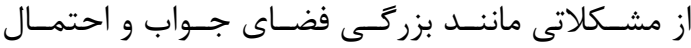

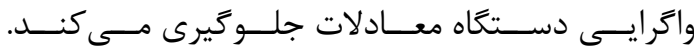

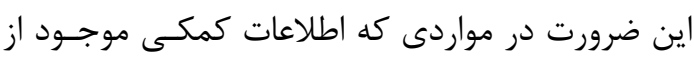

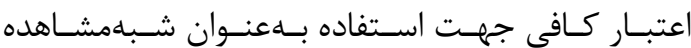
برخوردار نباشند، بارزتر خواهد بـود. در خنسين حـالتى

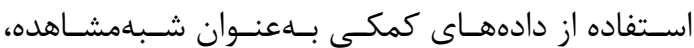

6 Perturbations

7 Quasi Observations
- 1 - - 1قدمه

مدلســازى هندسـى تصــاوير مـــاهوارهاى بــهـنــــوان اولين ضرورت در فرآيند تهيهى اطلاعات مكانى دقيق و

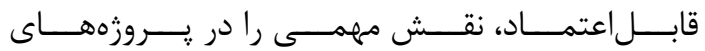

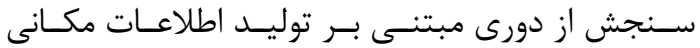

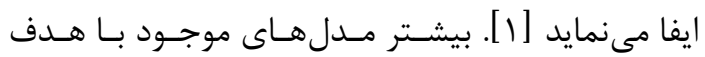
تامين حداكثرى دقت (بـر اسـاس كـاربرد مــورد نيـاز)،

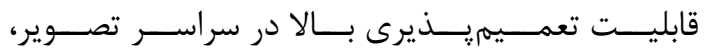

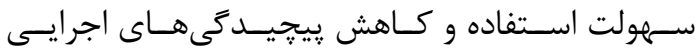
توسـعه يافتــه و بــا يكـديخر در رقابـت هســتـند [ب].

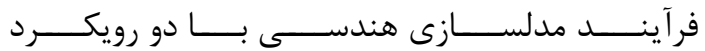

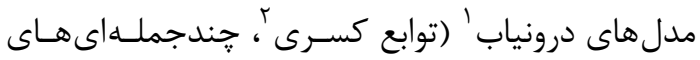

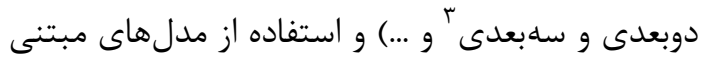
بر فيزيك تشكيل تصوير صورت مى يذيرد [ب و ب]

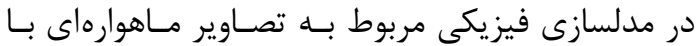

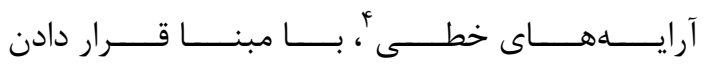

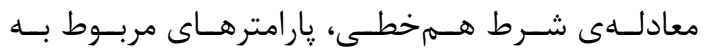

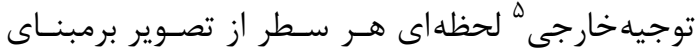
شرايط حركتى و وضعيتى سـنجنده تعيـين مسى گـردد

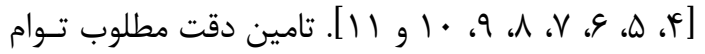

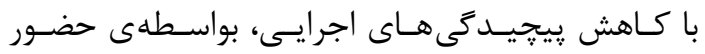
كمترين يارامترهاى موجود در ساختار مدلسازى يكى از

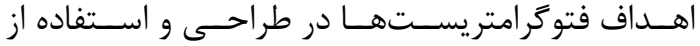

$$
\text { مدل هاى فيزيكى محسوب مىشود. }
$$

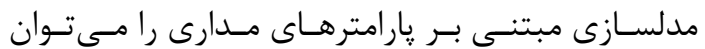

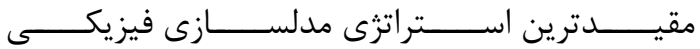

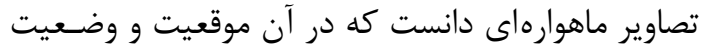

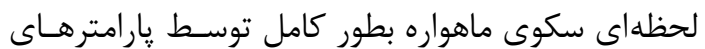

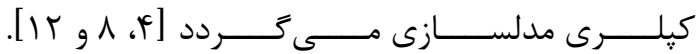
در اين استراتثى، سكوى ماهواره عموماً حركتى منطبق مدى مدرى

1 Interpolative Models

2 Rational Functions

3 2D \& 3D Polynomials

4 Linear Pushbroom Imagery

5 Exterior Orientation Parameters 
جهار سيستممختصات سهبعدى و ارتباط لحظهاى ميان

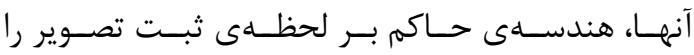

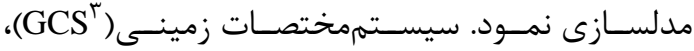

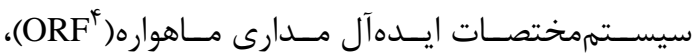

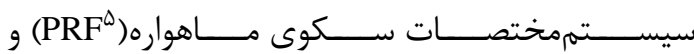

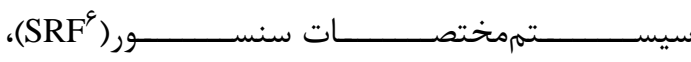
جهار سيستممختصـات مطـرح در مدلسـازى هندسى سئس تصاوير ماهوارهاى مىباشند. بCS بهنوان مبناى تعيين مختصات در فضاى زمين،

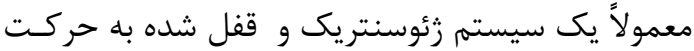

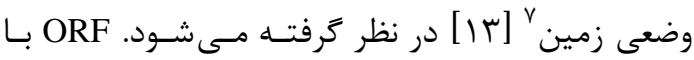

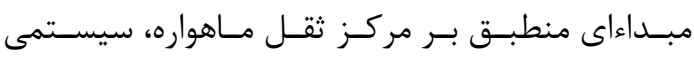

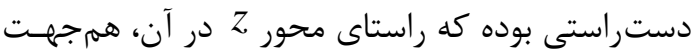

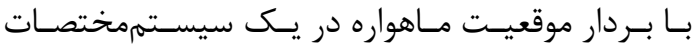

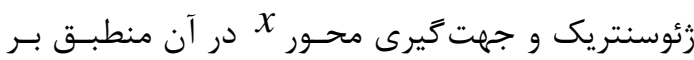

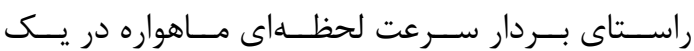

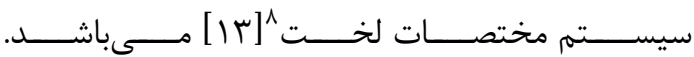
نيز هممبداء با ORF بوده كـه نسـبت بــه بدنسهى

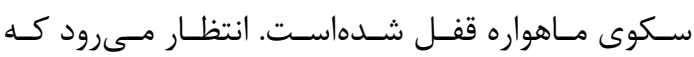

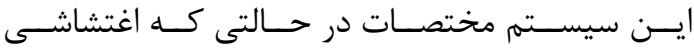

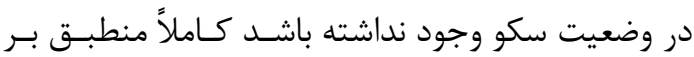

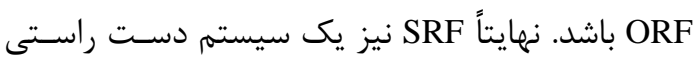

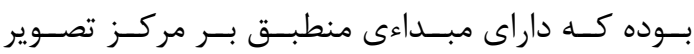
سيستم ايتيكى سـنجنده مسىباشـد. راسـتاى محـور

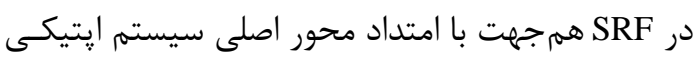

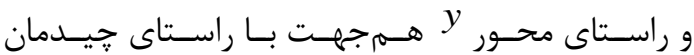

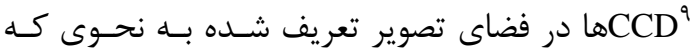

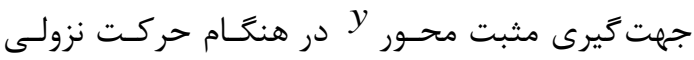
ماهواره به سمت شرق جغرافيايى معطوف خواهدبود.

3 Ground Coordinate System

4 Orbital Reference Frame

5 Platform Reference Frame

6 Sensor Reference Frame

7 Earth Fixed -Geocentric Coordinate System

8 Inertia / Space fixed Coordinate System

9 Charge Coupled Devise (CCD)
مشكلات مربوط به تعيين وزن مناسب براى هر يـارامتر

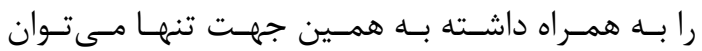
مقـــادير مـــذكور را بــــه عنـــوان مقـــادير اوليـــهـه در حل دستغاه معادلات در نظر گرفت. دانش نسبت بـه ميـزان وابسـتخى يارامترهـاى مـدل و

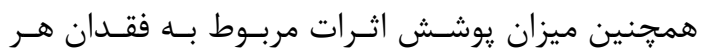
يارامتر در سـاختار مدلسـازى توسـط سـاير يـارامترهـا

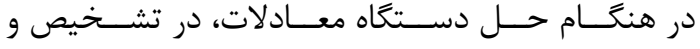
ردهبندى اهميت حضور هر :ارامتر در ساختار مدلسازى هر

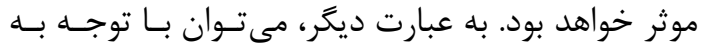

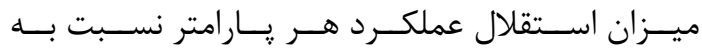
ساير : يارامترهـاى موجـود، در مــواقعى كـهـ اغتشاشـات

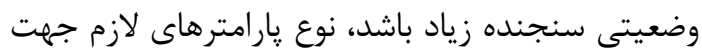

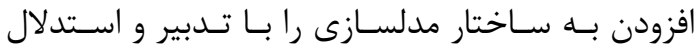
نسبت به سطح همبستخى بين يارامترها انجام داد. مقالهى پيش رو در جههار بخش اصلى تنظيمم شدهاست.

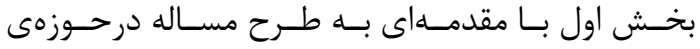
استفادهى اجرايى از مدل يارامترهاى مدارى مىيـردازد.

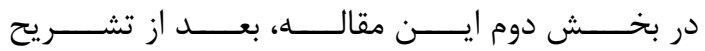

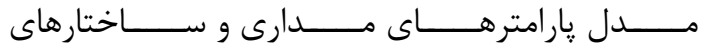

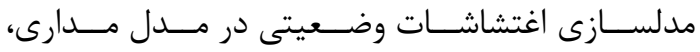
مجموعدى دادههاى مــورد اسـتفاده معرفى مسى خـردد.

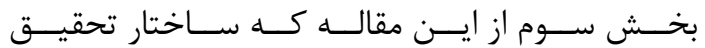
صورت پذيرفته را شامل مى شود، روند اجراى تحقيـق را

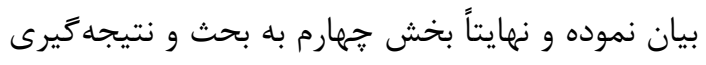

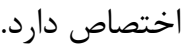

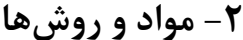

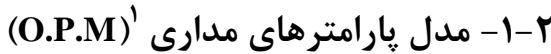

در تشكيل يك صحنه بَ با هندسهى تصويربردارى خطى در ســكوهــاى مــاهوارهاى، شــــايط فيزيكـى خاصـى

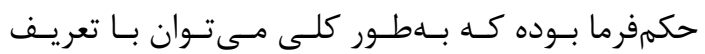

1 Orbital Parameter Model

2 Scene 
خواهنــدبــود. در ايــن ســاختار مدلســازى، مــاتريس $\left[R_{\text {Orbital }}\right]$ و ماتريس [Rttitude زمان و يا مستقل از زمان خواهدبود.

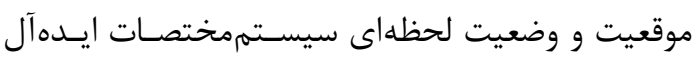

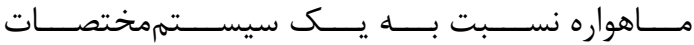
رئوسنتريك لخت و قفـل بـهـ فضـا، توسـط يَارامترهـاى

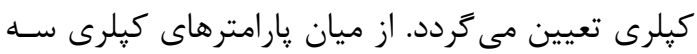

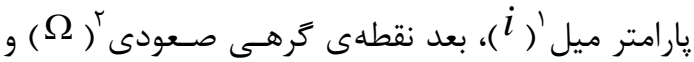

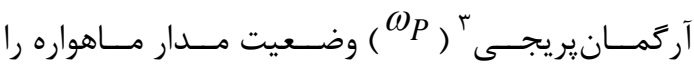

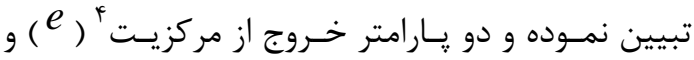

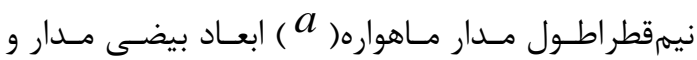

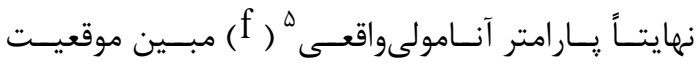

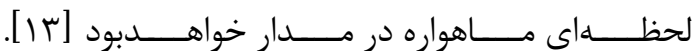

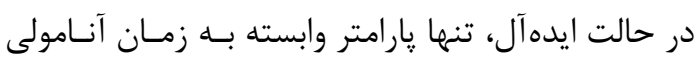

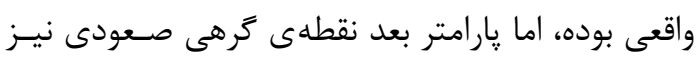

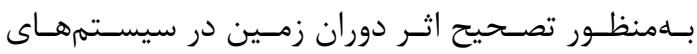

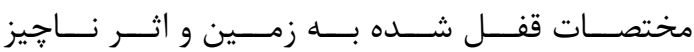
نرخ تغييرات $\Omega$ به زمان در مدارهاى خورشيدآهنـع

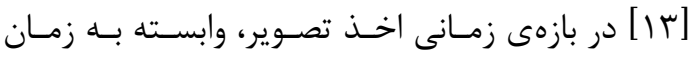
در نظر گرفتهمىشود(رابطهى r).

$$
\begin{aligned}
& \Omega=\Omega_{0}+\Omega_{1} \mathrm{t} \\
& \mathrm{f}=\mathrm{f}_{0}+\mathrm{f}_{1} \mathrm{t}
\end{aligned}
$$

(r) رابطه

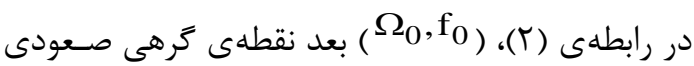

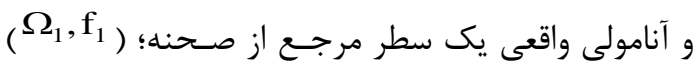

1 Inclination

2 Right Ascension of the Ascending Node

3 Argument of Perigee

4 Eccentricity

5 True Anomaly

6 Sun Synchronize
حركت ماهوارهها توسط قوانين كيلرى قابل تشريح بوده و صــرفنظر از اغتشاشـات و نيروهــاى خــارجى مــوثر،

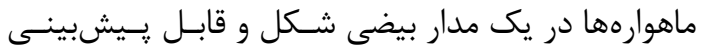

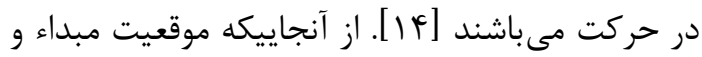
راستاى محور سـوم سيسـتم مختصـات ايـدهآل(ORF)

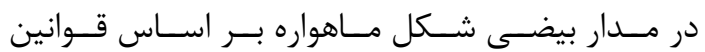
مكانيك سماوى در حال تغيير است، موقعيت و وضعيت سيستممختصات ايـدهآل مــدارى مـاهواره بـه يكـديكر وابسته و تابعى از يارامترهاى كيلرى خواهندبود.

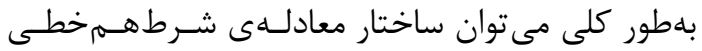

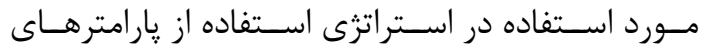

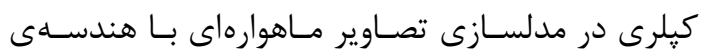
تصويربردارى خطى را بهصـورت سـاختار كلى موجـود در رابطهى (1) نشان داد (9).

(1) رابطه $\left(\begin{array}{c}X-X_{S} \\ Y-Y_{S} \\ Z-Z_{S}\end{array}\right)_{G C S}=\lambda\left[R_{\text {Orbital }}\right] \times\left[R_{\text {Attitude }}\right] \times\left[R_{\text {Pointing }}\right] \times\left(\begin{array}{c}x=0 \\ y \\ -c\end{array}\right)_{S R F}$ در رابطهى( (1)، (x,y) مختصات نقاط در فضاى تصـوير با هندسهى خطى و تكنولـوزى يـوشبـروم در سيسـتم SRF إِتيكى؛

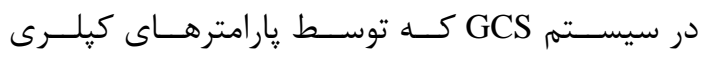
تعيين مىشود؛ $]^{T}$ سيستم GCS؛ $\lambda$ ضريب مقيـاس؛ لـ لـ

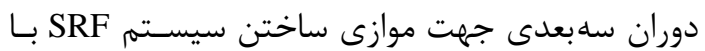
سيستم PRF بـه كمـك زوايـاى نشـانه روى ســنجنده،

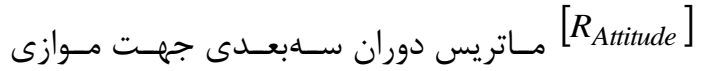

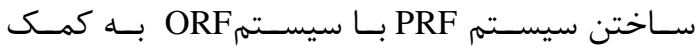
مدلسازى اغتشاشات وضعيتى ماهواره و $\left[R_{\text {Orbital }}\right.$ نيز ماتريس دوران سهبعدى جهت موازى سـاختن سيسـتهم

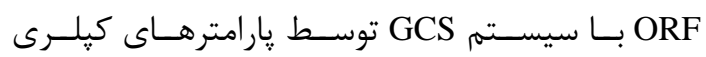


موجب تغيير وضعيت بدنهى سكوى ماهواره نسـبت بــه

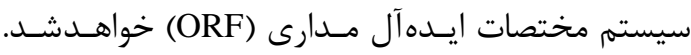
سيستمهاى ناوبرى تعبيه شده در مـاهواره، همــواره بــا

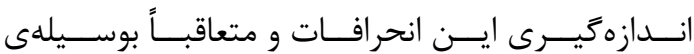
اعمال نيـروهــاى گشـتاورى سـعى بـر مــوازى سـاختن

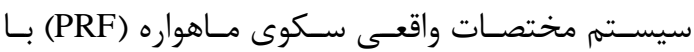

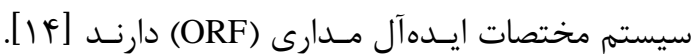

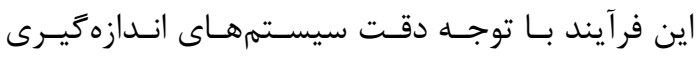

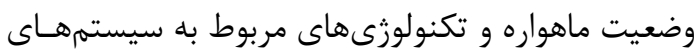

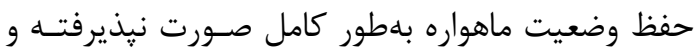
اغتشاشات تصحيح نشدهى اندكى در وضـعيت مـاهواره

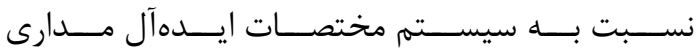
باقى خواهند مانـد. مـاتريس [ن

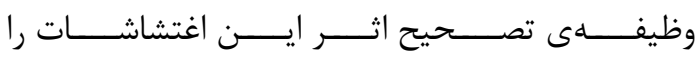

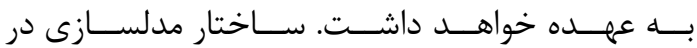
اين ماتريس بهصورت توابعى مستقل يا وابسته به زمـان

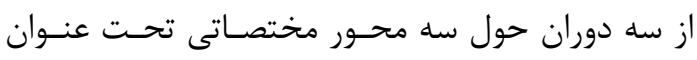

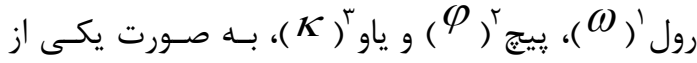
تركيبات موجود در رابطهى (ه) استفاده مىشود [9]. $\omega=\omega_{o}$

a)

$$
\varphi=\varphi_{o}
$$$$
\kappa=\kappa_{o}
$$

b)

$$
\omega=\omega_{o}+\omega_{1} \mathrm{t}
$$

)

$$
\varphi=\varphi_{o}+\varphi_{1} \mathrm{t}
$$$$
\kappa=\kappa_{o}+\kappa_{1} \mathrm{t}
$$

c)

$$
\begin{aligned}
& \omega=\omega_{o}+\omega_{1} \mathrm{t}+\omega_{2} \mathrm{t}^{2} \\
& \varphi=\varphi_{o}+\varphi_{1} \mathrm{t}+\varphi_{2} \mathrm{t}^{2} \\
& \kappa=\kappa_{o}+\kappa_{1} \mathrm{t}+\kappa_{2} \mathrm{t}^{2}
\end{aligned}
$$

1 Roll

2 Pitch

3 Yaw
(ه) (ه.بط $\left[R_{\text {Orbital }}\right]=\left[R_{3}(\pi-\Omega) \times R_{1}\left(i-\frac{\pi}{2}\right) \times R_{2}\left(\frac{\pi}{2}-\left(\omega_{P}+\mathrm{f}\right)\right)\right]$

نرخ تغييرات ( $\left.\Omega_{0}, f_{0}\right)$ نسبت به زمان در بازمى زمـانى

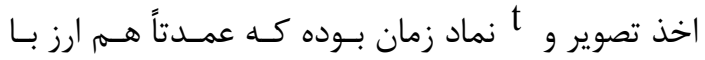
شمارoى سطر در فضاى تصوير لحاظ مىشود.

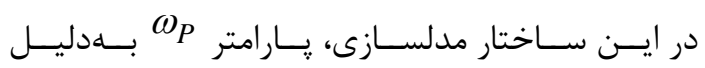

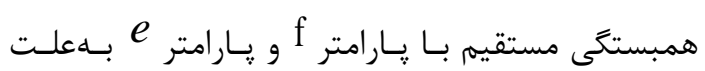

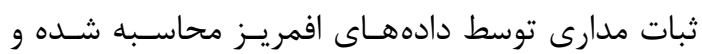

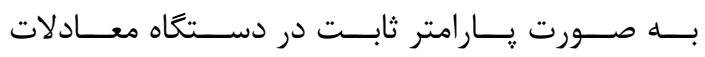
حضور ييدا مى كنند [9]. وضـعيت لحظــهاى سيسـتممختصــات ايسـدهآل مـدارى لئند (GCS)

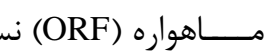
توسط ماتريس دوران [Rrbital $]$ قابل تشريح بوده كـه

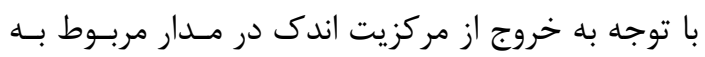

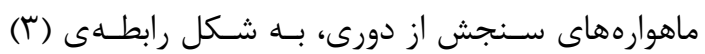

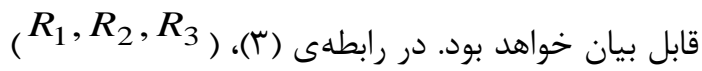
به ترتيب ماتريس هاى دوران سه بعدى حول سه محسور مى باشند. رابطه (广)

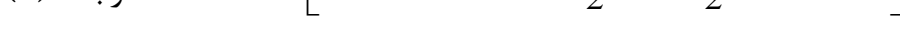
از آنجاييكه طول بردار شعاعى موقعيت لحظهاى ماهواره

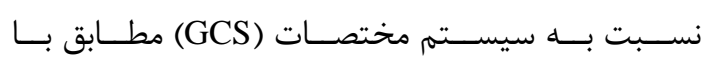

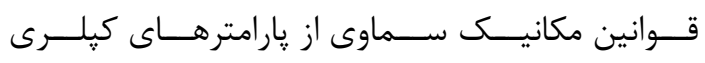

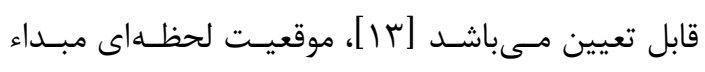
سيستم مختصات ايسدهآل مـدارى مـاهواره در سيسـتم فيسم (GCS) (i) (ابطه $\left[X_{S}, Y_{S}, Z_{S}\right]^{T}=\left[R_{\text {Orbital }}\right] \times[0,0, r]^{T}$

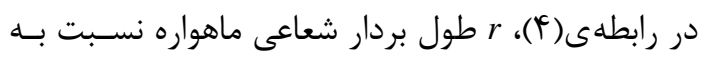
مبداء سيستم (GCS) مىباشد. r-Y - مدلسازى اغتشاشات وضعيتى سنجنده بديهى است كه نيروهاى خارجى موثر بر ماهواره موجب

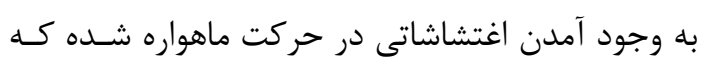


r-r-r - مجموعهى دادههاى مورد استفاده

بــهـ منظــور بررســى امكــان اســفاده از مــدل صــلب

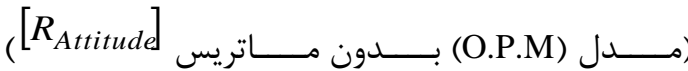

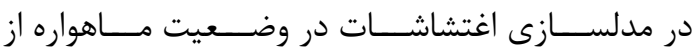

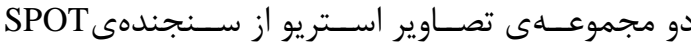
مربوط به دو شهر زنجان و اصـفهان و يـك مجموعـهى مئى

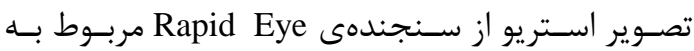

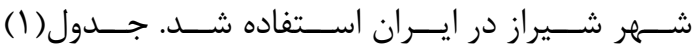

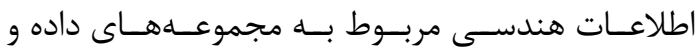

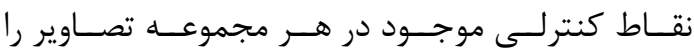
نشان مى دهد. نقاط كنترلـى در دو منطقـهى زنجــان و

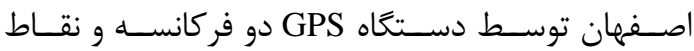
كنترلى در منطقهى شـيراز از روى نقشـهى شـهـرى بــا مقياس 1:2000 جمع آورى شدهاند. از سوى ديخر نقـاط كنترلــى در فضــاى تصــوير، در مجموعــهى تصــاوير منطقهى شهر زنجان بـا دقـت تقريبـى نـيم بيكسـل و

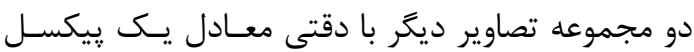
اندازهخيرى شدهاند. جيدمان نقاط كنترلى در فضاى تصاوير مربـوط بـهـ هــــ مجموعـهـى داده و نحــوهى تيوشــش تصــاوير اســتريو در شكل (1) نشان داده شدهاست. تمامى تصاوير مورد استفاده در اين تحقيق فاقد هر گونه تصحيح هندسى بوده و اطلاعات افمريز آنهـا در اختيـار قرار داشت. در هر تصـوير بـهـ كمـك اطلاعـات افمريـز

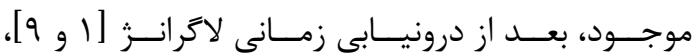

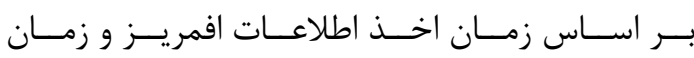

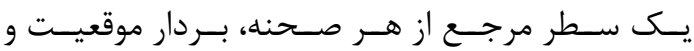

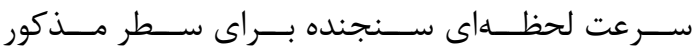

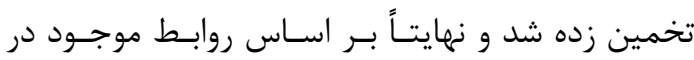

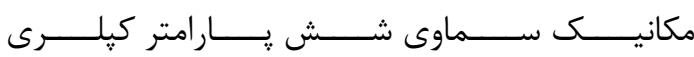
(a,e, $\left.i, \Omega_{o}, \omega_{P}, \mathrm{f}_{\mathrm{o}}\right)$ محاسبه گرديد [11]].
تعداد و نوع ترمهاى مورد استفاده از جندجملـهاىهـاى

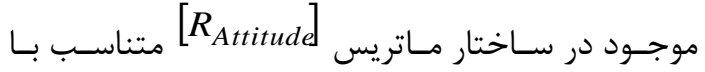
ميزان اغتشاشات موجود در بـازمى زمـانى اخــذ تصـوير بوده كه بر اساس ميـزان تـاثير در دقت بــرازش مــدل

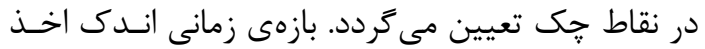

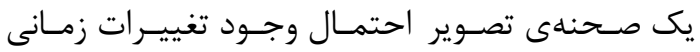
فاحش و غيرخطى را در اغتشاشات منتفى مسىسـازد و

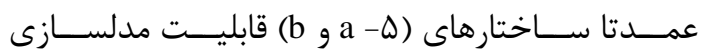
اغتشاشات وضعيتى را به نحو مطلوبى تامين مى كنند. در ادامه به نقد ساختار مدل حل اغتشاش در استراترى

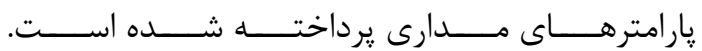
تعدد ماتريسهاى دورانى موجب بزرگى فضاى جــواب و همجنين نزديكى مقادير جواب به يكديگر خواهند شـد؛

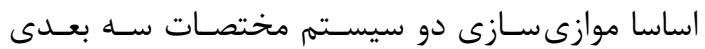

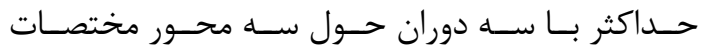
ممكن خواهد بود. در صورت دقيق نبودن مقادير اوليه و

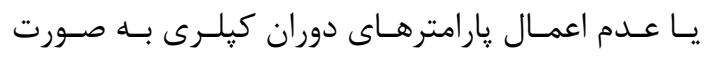

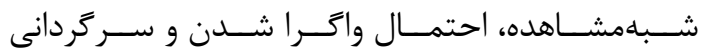
در فضاى جواب افزايش مسىيابـد كـهـ موجـب تخمـين

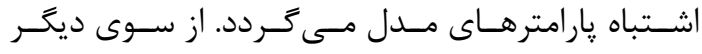

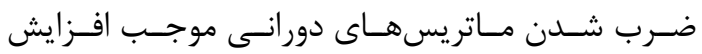
ييجيد گى خطى سازى معادلهى شرطهمخطى نسبت به يارامترهاى مدل نيز خواهد شد.

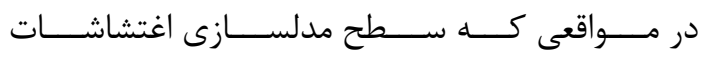

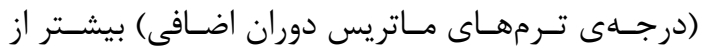

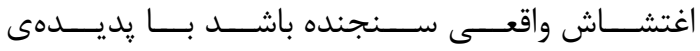

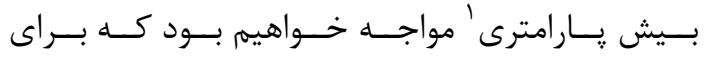

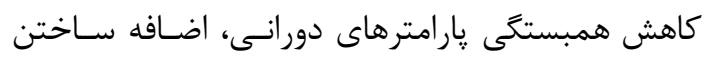

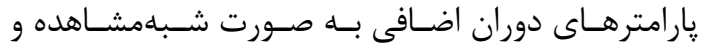
تعيين وزن مناسب براى آنها جهت جلوگيرى از واكرايى و سركردانى دستخاه معادلات امرى ضرورى مى بـاشد.

1 Over Parameterization 
بررسى سطوح همبستكىى بين يار امترهـاى مـدل مـدارى...

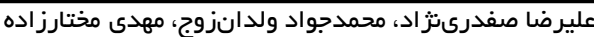

جدول ا : مجموعدى دادهها و اطلاعات مربوط به هر كدام

\begin{tabular}{|c|c|c|c|c|c|c|}
\hline \multicolumn{2}{|c|}{ زنجان } & \multicolumn{2}{|c|}{ اصفهان } & \multicolumn{2}{|c|}{ 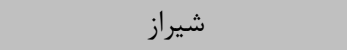 } & مجموعه داده \\
\hline \multicolumn{2}{|c|}{ SPOT-3 } & \multicolumn{2}{|c|}{ SPOT-1 } & \multicolumn{2}{|c|}{ Rapid Eye-2 } & 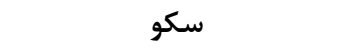 \\
\hline \multicolumn{2}{|c|}{ HRV } & \multicolumn{2}{|c|}{ HRV } & \multicolumn{2}{|c|}{ Green-Band* } & سنجنده \\
\hline July 1993 & July 1993 & Aug 1987 & Jun 1987 & Mar 2010 & Mar 2010 & تاريخ اخذ \\
\hline $19.01 \mathrm{~W}$ & $16.66 \mathrm{E}$ & $24.7 \mathrm{~W}$ & $20.84 \mathrm{E}$ & $19.64 \mathrm{~W}$ & $7.09 \mathrm{E}$ & زاويه ديد (درجه) \\
\hline \multicolumn{2}{|c|}{$10 \mathrm{~m}$} & \multicolumn{2}{|c|}{$10 \mathrm{~m}$} & \multicolumn{2}{|c|}{$6.5 \mathrm{~m}$} & قدرت تفكيك مكانى در نادير \\
\hline \multicolumn{2}{|c|}{0.737} & \multicolumn{2}{|c|}{0.974} & \multicolumn{2}{|c|}{0.534} & نسبت باز به ارتفاع \\
\hline \multicolumn{2}{|c|}{31} & \multicolumn{2}{|c|}{35} & \multicolumn{2}{|c|}{34} & تعداد نقاط كنترل \\
\hline
\end{tabular}

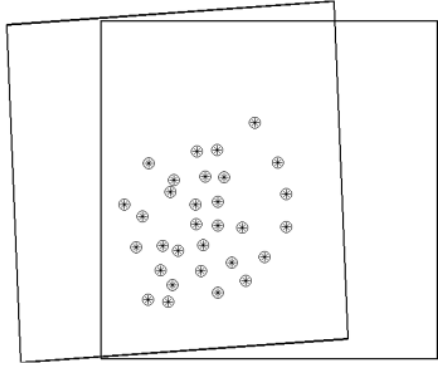

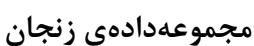

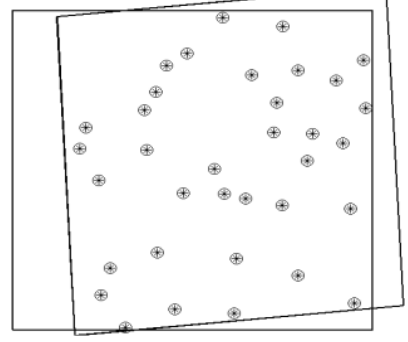

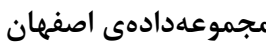

شكل ا : توزيع نقاط كنترلى در هر مجموعه داده

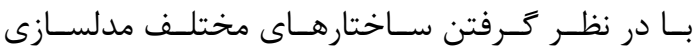
اغتشاش (رابطـهى ه)، در همخرايسى دسـتخاه معـادلات

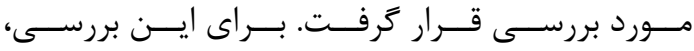

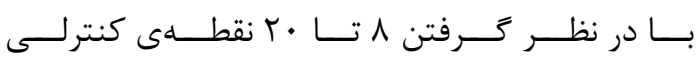
در هر مجموعهى داده، حل دستخاه معادلات بـهمنظــور برآورد يارامترهاى مدل صورت يذيرفت.

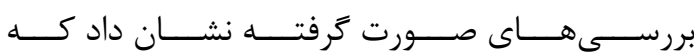

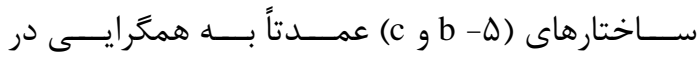
دستخاه معادلات منجر نشده و ساختار (a-a بيشـترى بــه همخرايـى مـى انجامــــ بــا غربــال نتــايج

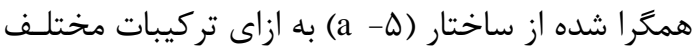
نقــاط كنترلـى، بــه بررسـى ميـزان همبســتخى ميــان

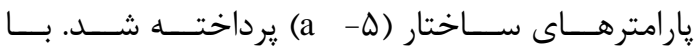

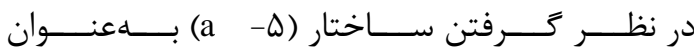

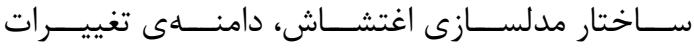

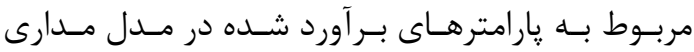

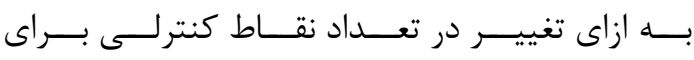
هر مجموعهى داده در جدول (r) نشان داده شده است.

"باندهاى تصاوير خام سنجندهى Rapid Eye هم مرجع نيستن

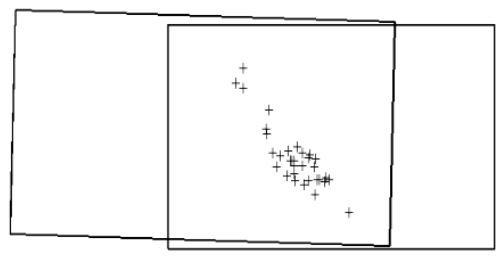

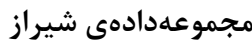

ץ- - بيادهسازى و نتايج

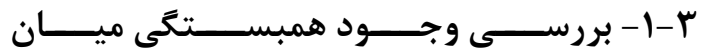
يار امتر هاى مدل مدارى وجود همبستخى بين پارامترهاى مـدل مـدارى، امكـان

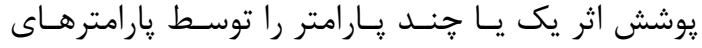

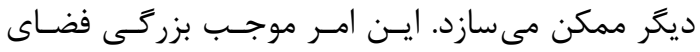

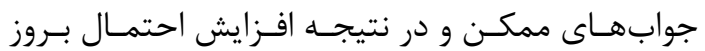

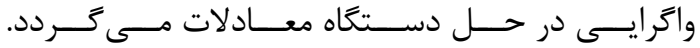
افزودن گارامترهاى مدل مدارى به صورت شبهمشـاهده

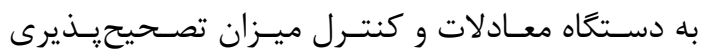
هر يارامتر به كمـك مقـادير وزن، راهكـار جلـوگيرى از

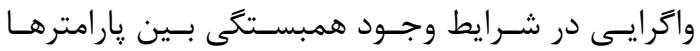
محسوب مسى شـود. بـا توجـهـ بـه معايـب مطـرح شـده در مدل يارامترهاى مدارى، اين بخش با هـدف نمايـان

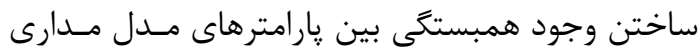
تدوين شده است.

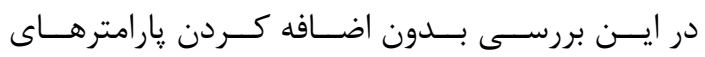
مدل مدارى بهصورت شبهمشـاهده، توفيـق ايسن مـدل 
در ســطح نتــايج تقــاطع فضـايى بـراى نقــاط جـــ

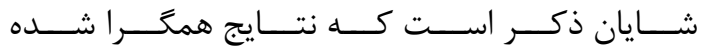
تامين نمودند.

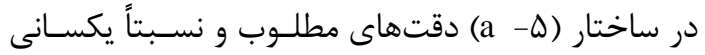

جدول r: دامنهى تغييرات يارامترهاى بر آورد شدهى مدل مدارى با ساختار اغتشاش (هاى (a (a) به ازاى تعداد مختلف نقاط كنترل

\begin{tabular}{|c|c|c|c|c|c|c|c|c|c|c|}
\hline Dataset & Parameter & $\begin{array}{c}a \\
(\mathbf{K m})\end{array}$ & $\begin{array}{c}i \\
(D e g)\end{array}$ & $\begin{array}{c}\mathbf{f}_{\mathbf{0}} \\
(\text { Deg })\end{array}$ & $\begin{array}{c}\Omega_{0} \\
(\text { Deg })\end{array}$ & $\begin{array}{c}\omega_{0} \\
(\text { Deg })\end{array}$ & $\begin{array}{c}\varphi_{0} \\
(D e g)\end{array}$ & $\begin{array}{c}\boldsymbol{\kappa}_{\mathbf{o}} \\
(\text { Deg })\end{array}$ & $\begin{array}{c}\mathbf{f}_{\mathbf{1}} \\
(\text { Deg/Line })\end{array}$ & $\begin{array}{c}\mathbf{\Omega}_{1} \\
(\text { Deg/Line })\end{array}$ \\
\hline \multirow{2}{*}{ زنجان } & تصوير اول & 6.96 & 19.49 & 1.21 & 14.17 & 0.63 & 1.07 & 23.97 & $5.0 \mathrm{E}-06$ & 4.6E-05 \\
\hline & تصوير دوم & 5.79 & 17.99 & 0.65 & 12.62 & 0.86 & 1.01 & 21.94 & $2.6 \mathrm{E}-06$ & 4.2E-05 \\
\hline \multirow{2}{*}{ اصفهان } & تصوير اول & 17.46 & 10.09 & 1.14 & 6.81 & 0.99 & 3.91 & 11.99 & $5.3 \mathrm{E}-06$ & 2.3E-05 \\
\hline & تصوير دوم & 8.75 & 8.81 & 0.87 & 5.64 & 0.82 & 3.02 & 10.51 & $2.0 \mathrm{E}-06$ & $1.9 \mathrm{E}-05$ \\
\hline \multirow{2}{*}{ شيراز } & تصوير اول & 12.62 & 28.97 & 0.90 & 16.50 & 3.58 & 11.36 & 33.38 & $9.9 \mathrm{E}-06$ & $1.2 \mathrm{E}-04$ \\
\hline & تصوير دوم & 61.87 & 36.63 & 2.06 & 22.07 & 5.39 & 12.89 & 42.01 & $2.2 \mathrm{E}-05$ & $1.6 \mathrm{E}-04$ \\
\hline
\end{tabular}

توسـط پارامترهـاى مــدل صـلب مـدارى در سـهـ كَام، مورد بررسى و ارزيابى قرار كرفت.

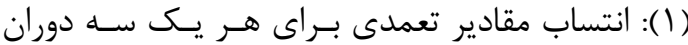

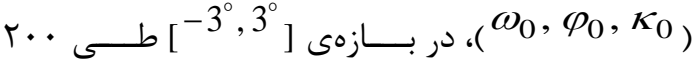

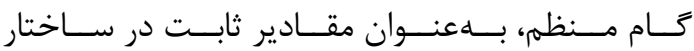

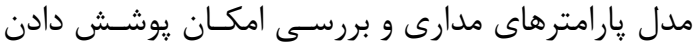

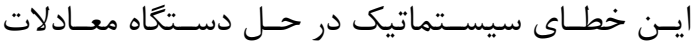

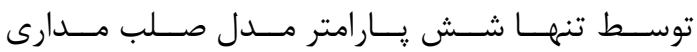

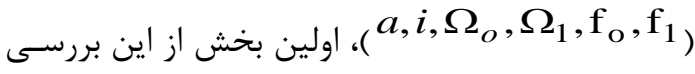

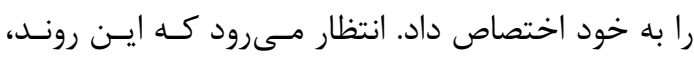
امكان مدلسازى اغتشاشات موجود در وضعيت سنجنده به كمك يتانسيل پارامترهاى مدارى را مشخص نمـوده؛

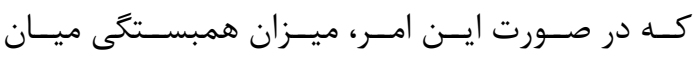
يارامترهاى مدارى و دورانهاى اضافى اثبات مى شود.

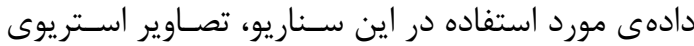

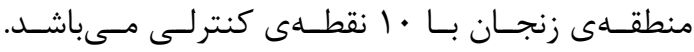

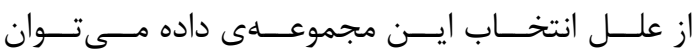

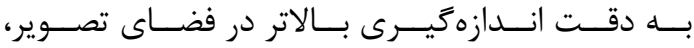

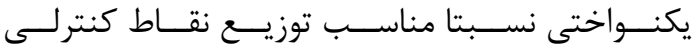

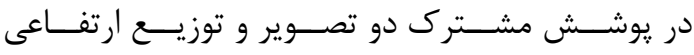
مناسبتر نقاط كنترل زمينسى در ايـن مجموعـهى داده نسبت به ساير مناطق مورد مطالعه، اشاره نمود.

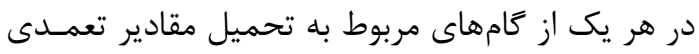

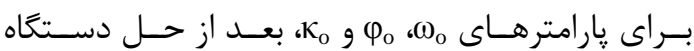

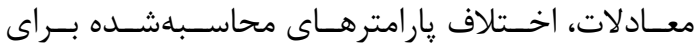

همانكَونه كه در جدول فوق ديده مىشود، تنها با تغييـر

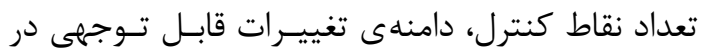

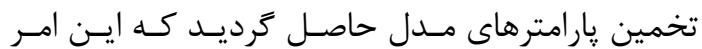
كوياى گستردىى فضاى جواب براى دسـتخاه معـادلات مى باشد. از طرفى دقت مناسب مدل مدارى در ارزيـابى

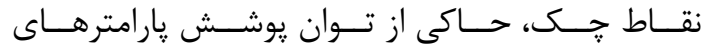
اين ساختار (a-a) در مدلسازى اثرات يكديكر مى باشد.

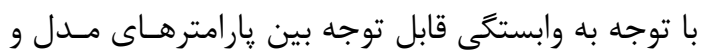
با هدف كاهش يار امترهاى موجود در ساختار مدلسازى، باري،

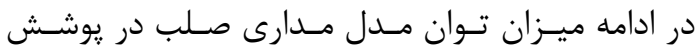

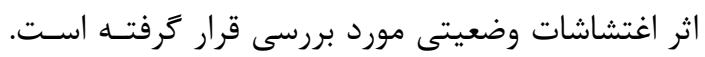

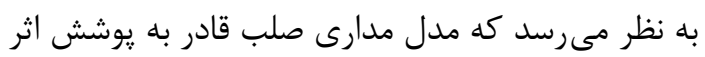
سطح محدودى از اغتشاشات مدارى بوده كـه در ادامـهـ در جندين كام تحليلى مورد بررسى قرار مى گيرد.

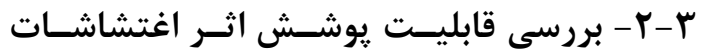
وضعيتى توسط مدل صلب مدارى بررسى توان يارامترهاى مدل صلب مدارى در مدلسازى

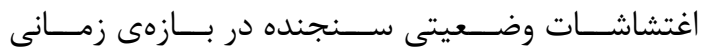

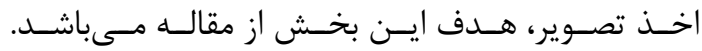

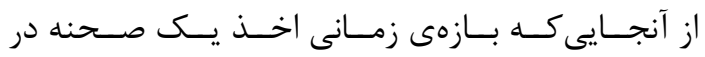

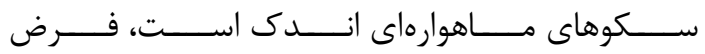
ثبات وضـعيت ســنجنده نسـبت بـه سيسـتممختصـات ايدهآل مـدارى (ORF) در بـازمى زمـانى اخـذ صحسنه،

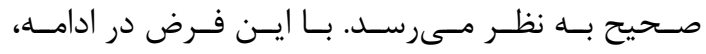

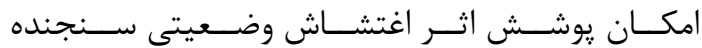




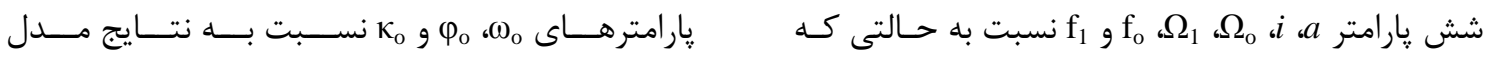

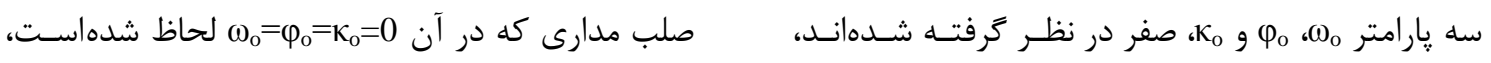

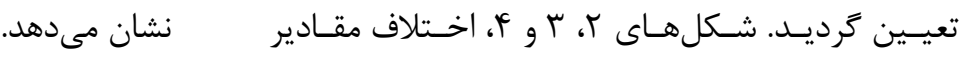
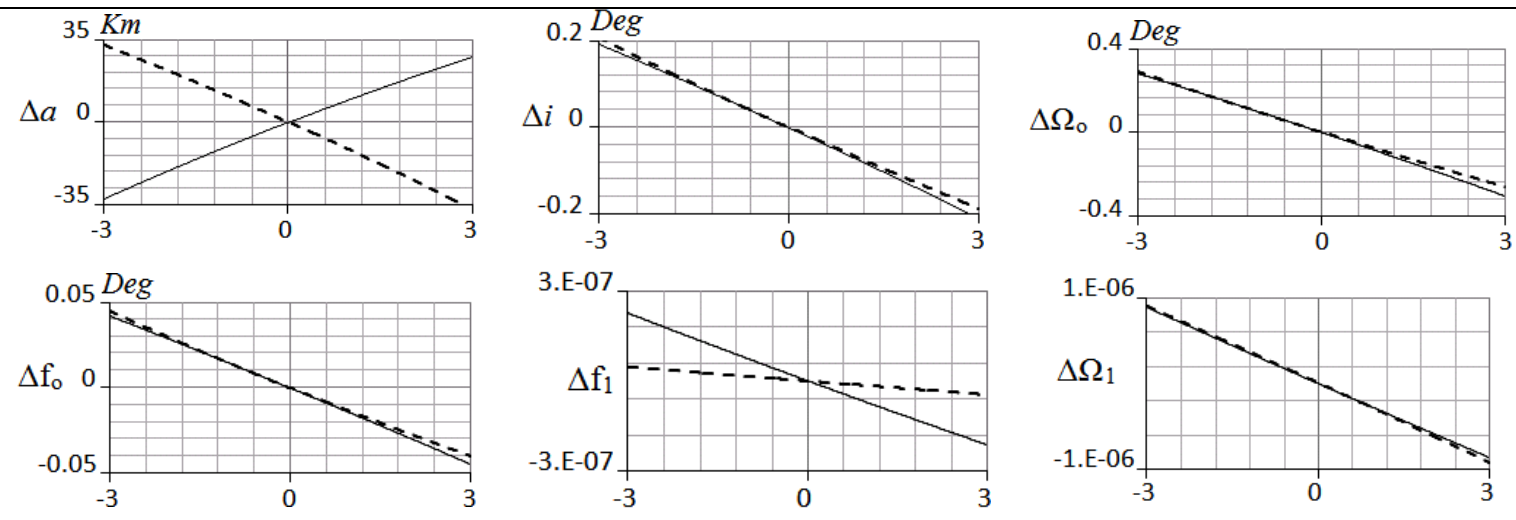

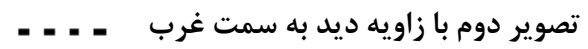

تصوير اول با زاويه ديد به سمت شرق

شكل r : تاثير افزودن تعمدى دوران اضافى ف با با نقش ثابت در تخمين يار امتر هاى مدل مدارى صلب
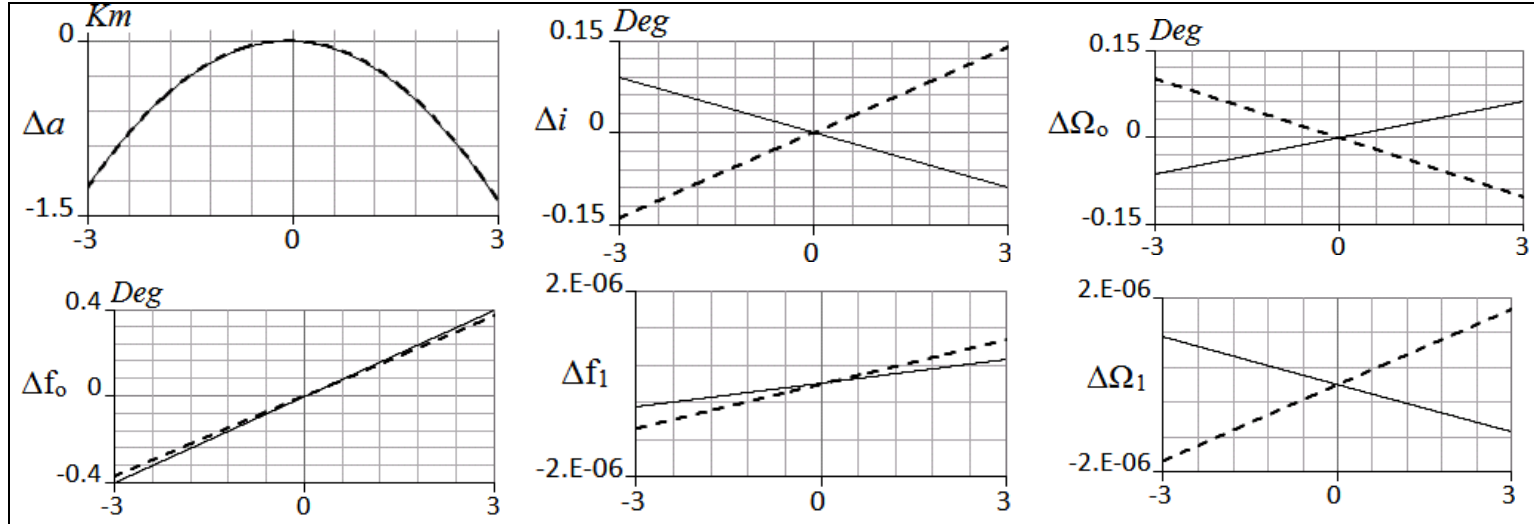

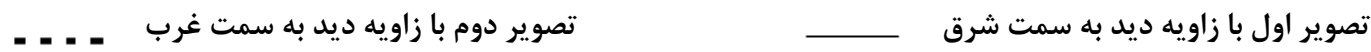

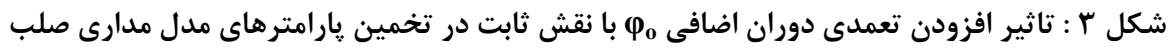
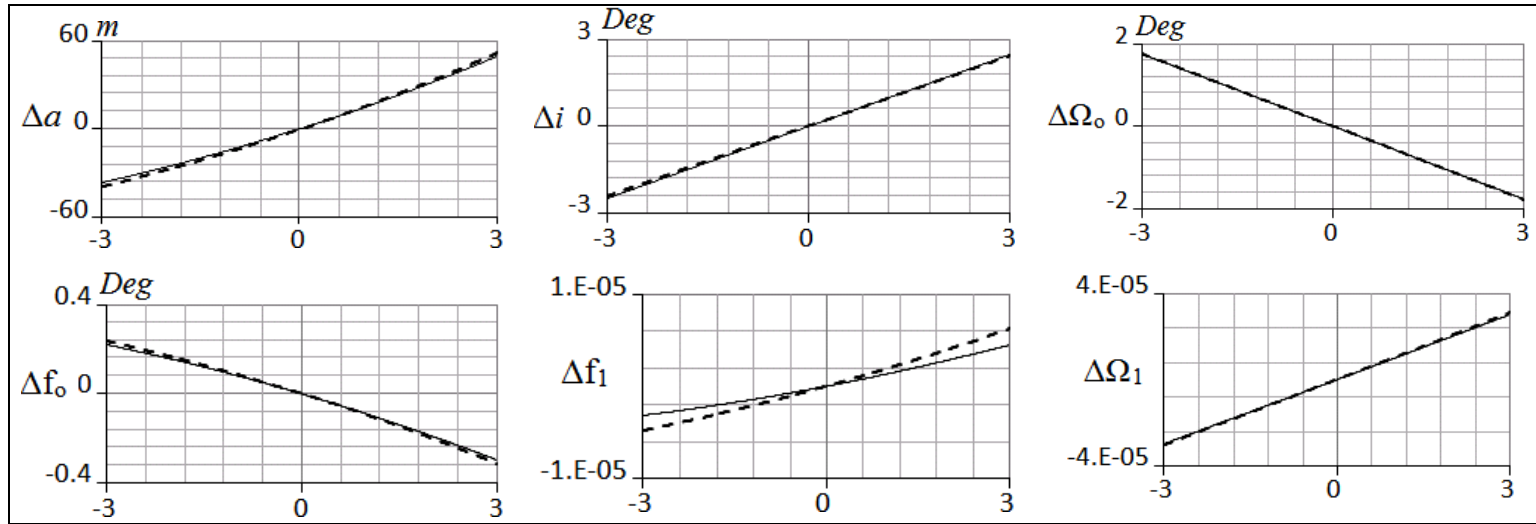

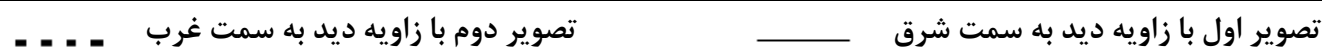

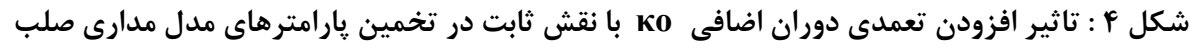


سنســور بـوده و برخــى ديخــر مسـتقل از ايــن عامـلـ رفتار مى كنند. در ادامــه ميـزان واقعـى همبســتخى، در تـاثيرى كــهـ اين سناريو بر دقت برازش مدل در نقاط كنترلى و جـ ايجاد مى كند، مورد ارزيابى قرار گرفته است. به عبـارت ديخر، در صورت استقلال دقت برازش مدل از اثر حضور مورد تعمدى هر يـك از يارامترهــاى دورانسى مطـرح در ايـن سـناريو(

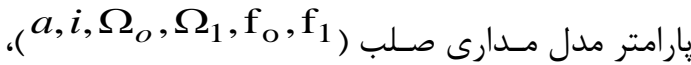

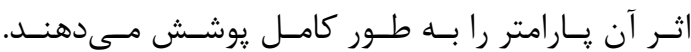
نمــودارهــاى موجــود در شـكل (ه)، تغييـرات RMSE مسطحاتى و ارتفاعى براى نتايج تقاطع فضـايى را بـراى مورد هـر يـــ از مــوارد بررسـى دورانهـــ نشان مى دهد.
محــور افـق نمودارهـاى موجــود در اشـكال(ז، آو أ)، مبين مقادير انتخاب شدهى براى هر يـك از سـه دوران

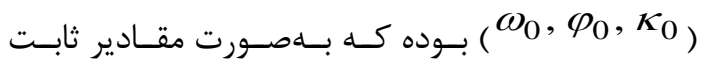
در ســاختار مــدل صــلب مــدارى لحـــاظ شــدهانـــ؛ و موقعيت در محور عمود نمودارهاى مورد بحث، ميزان اختلاف برآورد هـر يـك از يارامترهــــ مـدل صـلب بـاـ حضـور تعمـدى يارامترهـاى دورانـى ( $\omega_{0}, \varphi_{0}, \kappa_{0}$ را با مدلى كـه هـر يـك از سـه دوران در آن، مقادير صفر لحاظ شدهاند، نمايش مى بدهد. شايان ذكر است كـهـ نمودارهـاى مربـوط بـهـ مجموعـهـ

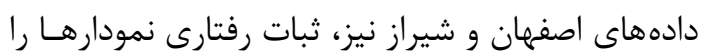

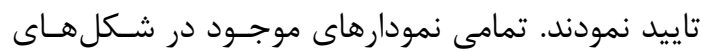

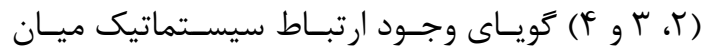
يارامترهــاى مــدارى و دورانهـاى مسـتقل از زمــان در

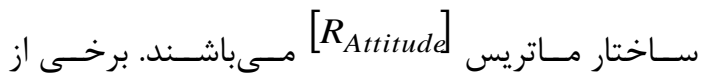
اثرات وابسته به جهت گيرى سنجنده توسط زواياى ديد

الف : ارزيابى دقت مسطحاتى در سيستم تصوير
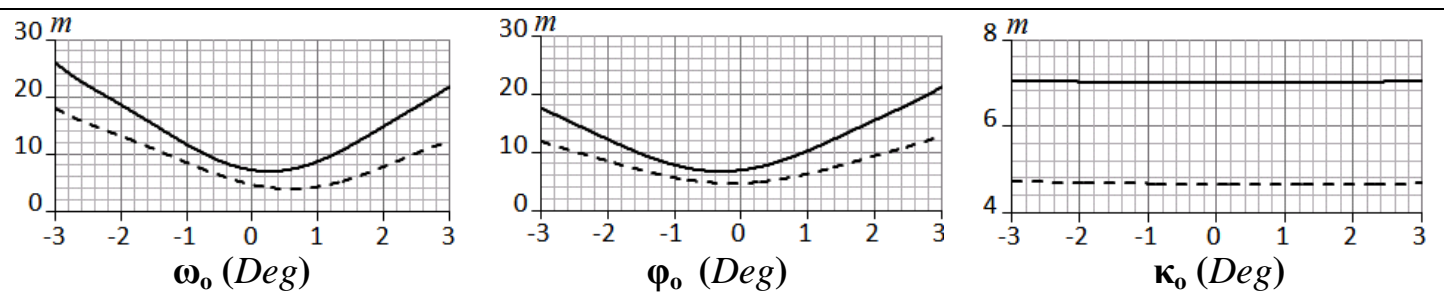

بTM ارزيابى دقت ارتفاعى در سيستم تصوير
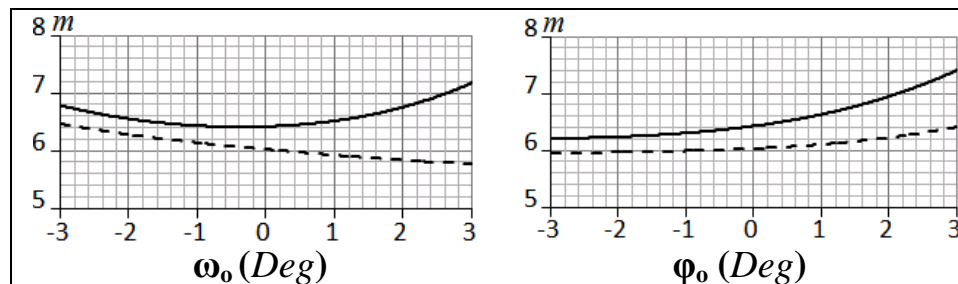

$\varphi_{\mathbf{o}}(\mathrm{Deg})$

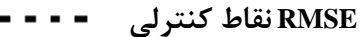

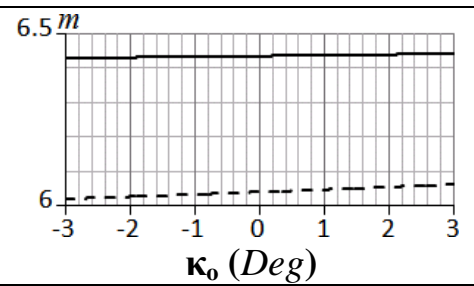

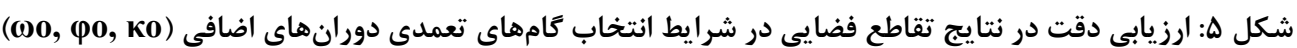

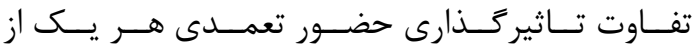
يارامترهــاى

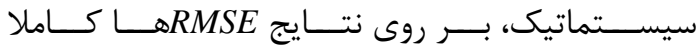

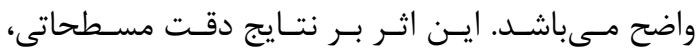

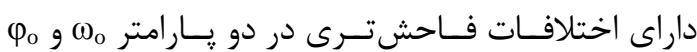
محور افق در نمـودارهــاى موجـود در شـكل (ه) داراى

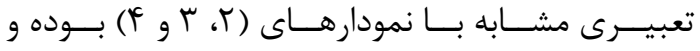

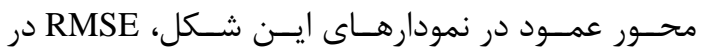
نقاط كنترل و جكى را در واحد متر نشان مىدهد. همانطور كه از نمودارهاى شكل (ه) مشاهده مسىشـود، 
براى هريك از 9 هـارامتر موجـود در سـاختار مـاتريس

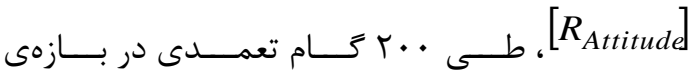

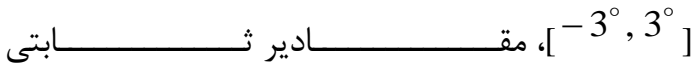

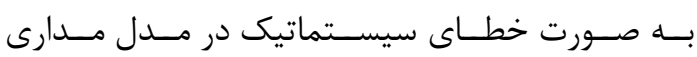
تحميل شد. در انتخاب مقادير تعمدى براى يارامترهاى

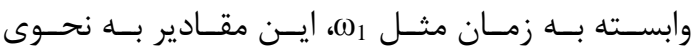
تعيين شدند كه در بازمى زمانى ابتدا تا انتهاى صحنهى تصوير زاويهاى به اندازهى مقدار تحميل شده در هر كاني كام

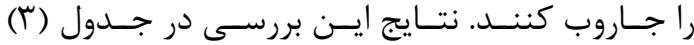

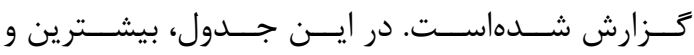

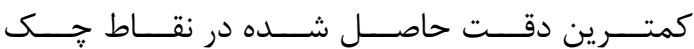
با تفكيك مولفهى مسطحاتى و ارتفاعى، به ازاى انتخاب كام هاى تعمدى هر ترم از ساختار ماتريس

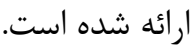

مىباشند. از اينروى به نظر مسرسـد كـه مــدل صـلب

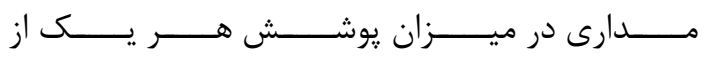
بارامتر هاى بـ

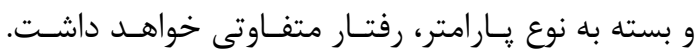

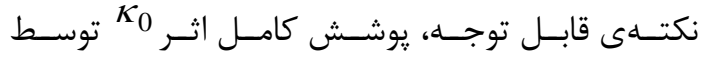

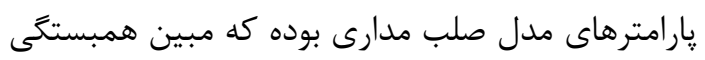
بالاى اين يارامتر با بار امترهاى مدارى مى باشاشد.

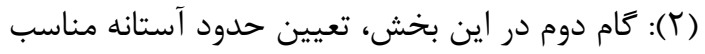

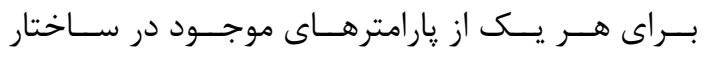

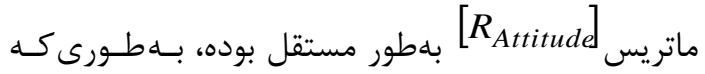

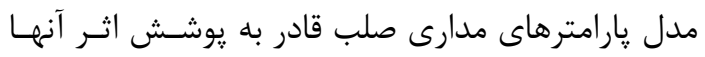

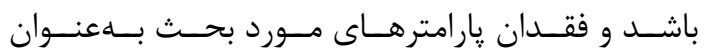

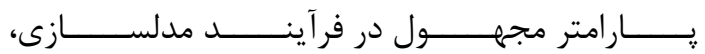

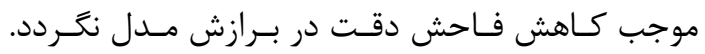

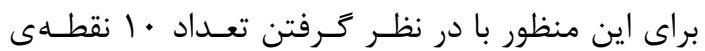

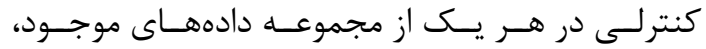

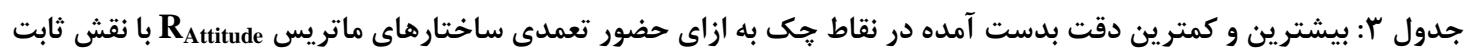
در حل دستكاه معادلات

\begin{tabular}{|c|c|c|c|c|c|c|c|c|c|c|}
\hline \multirow{2}{*}{\multicolumn{2}{|c|}{ مجموعدى دادهى زمهلى دادهها }} & \multicolumn{9}{|c|}{ يارامتر هاى ماتريس RAttitude } \\
\hline & & $\omega_{0}$ & $\omega_{1}$ & $\omega_{2}$ & $\varphi_{0}$ & $\varphi_{1}$ & $\varphi_{2}$ & $\kappa_{\mathbf{0}}$ & $\kappa_{1}$ & $\kappa_{2}$ \\
\hline \multirow{2}{*}{ Planimetric } & $\underset{(m)}{\operatorname{Max} \text { Rmse }}$ & 25.6 & 7.81 & 233.12 & 21.08 & 7.16 & 209.29 & 7.04 & 22.05 & 10.19 \\
\hline & $\begin{array}{c}\text { Min Rmse } \\
(m)\end{array}$ & 6.74 & 6.98 & 6.80 & 6.73 & 6.99 & 7.00 & 7.01 & 6.65 & 6.50 \\
\hline \multirow{2}{*}{ Orthometric } & $\begin{array}{c}\text { Max Rmse } \\
(m)\end{array}$ & 7.18 & 45.76 & 35.53 & 7.41 & 7.17 & 20.87 & 6.44 & 7.16 & 6.45 \\
\hline & $\begin{array}{c}\text { Min Rmse } \\
(m)\end{array}$ & 6.43 & 6.41 & 6.36 & 6.21 & 6.43 & 6.42 & 6.42 & 6.41 & 6.38 \\
\hline \multicolumn{2}{|c|}{ مجموعهى دادهى اصفهان } & $\omega_{0}$ & $\omega_{1}$ & $\omega_{2}$ & $\varphi_{0}$ & $\varphi_{1}$ & $\varphi_{2}$ & $\kappa_{\mathbf{0}}$ & $\kappa_{1}$ & $\kappa_{2}$ \\
\hline \multirow{2}{*}{ Planimetric } & $\begin{array}{c}\text { Max Rmse } \\
(m)\end{array}$ & 28.43 & 17.35 & 873.82 & 13.97 & 12.23 & 725.80 & 12.54 & 86.13 & 47.01 \\
\hline & $\begin{array}{c}\text { Min Rmse } \\
(m)\end{array}$ & 12.18 & 12.17 & 12.06 & 12.09 & 12.11 & 12.01 & 12.14 & 12.17 & 11.81 \\
\hline \multirow{2}{*}{ Orthometric } & $\begin{array}{c}\text { Max Rmse } \\
(m)\end{array}$ & 7.59 & 189.19 & 169.69 & 6.66 & 7.47 & 65.34 & 6.56 & 13.30 & 7.33 \\
\hline & $\begin{array}{c}\text { Min Rmse } \\
(m)\end{array}$ & 6.48 & 6.57 & 6.56 & 6.47 & 6.53 & 6.23 & 6.52 & 6.53 & 6.11 \\
\hline \multicolumn{2}{|c|}{ مجموعهى دادهى شيراز } & $\omega_{0}$ & $\omega_{1}$ & $\omega_{2}$ & $\varphi_{0}$ & $\varphi_{1}$ & $\varphi_{2}$ & $\kappa_{\mathbf{0}}$ & $\kappa_{1}$ & $\boldsymbol{\kappa}_{2}$ \\
\hline \multirow{2}{*}{ Planimetric } & $\begin{array}{c}\text { Max Rmse } \\
(m)\end{array}$ & 8.78 & 7.76 & 26.96 & 8.08 & 7.62 & 26.16 & 7.64 & 11.33 & 8.26 \\
\hline & $\begin{array}{c}\text { Min Rmse } \\
(m)\end{array}$ & 7.55 & 7.44 & 7.53 & 7.38 & 7.52 & 7.35 & 7.51 & 7.4 & 7.31 \\
\hline \multirow{2}{*}{ Orthometric } & $\underset{(m)}{\operatorname{Max} \text { Rmse }}$ & 4.86 & 16.89 & 6.11 & 4.82 & 4.81 & 5.40 & 4.82 & 5.13 & 4.85 \\
\hline & $\begin{array}{c}\text { Min Rmse } \\
(m)\end{array}$ & 4.62 & 4.17 & 4.23 & 4.81 & 4.66 & 4.38 & 4.81 & 4.78 & 4.79 \\
\hline
\end{tabular}




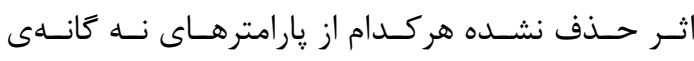

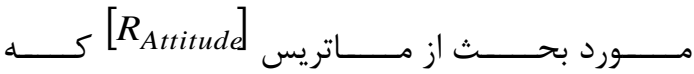
به صورت مقادير تعمدى و ثابت در مدل مدارى حضـور

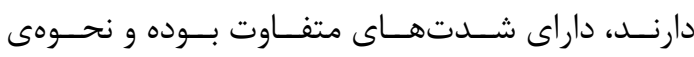

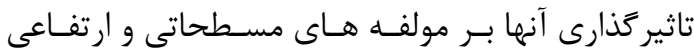
متفاوت مىباشند.

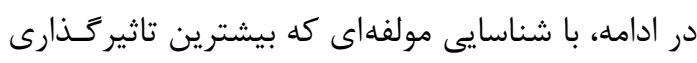
هر پارامتر به آن اختصاص دارد(مسطحاتى يا ارتفــاعى)،

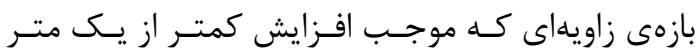

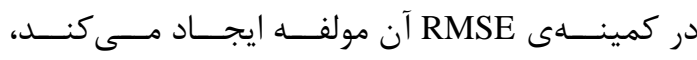

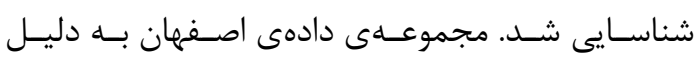

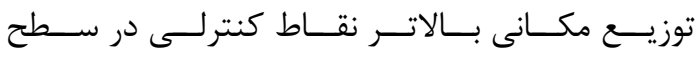

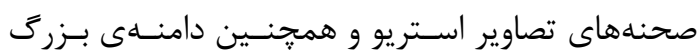

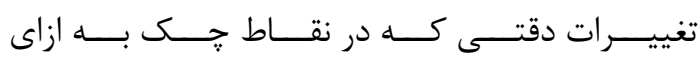
كَـامهـاى تعمـدى بارامترهــاى مـاتريس

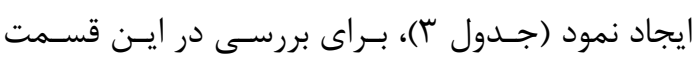

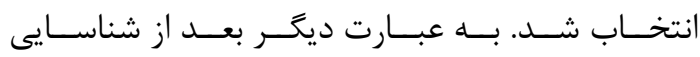
مولفهاى(مسطحاتى يا ارتفاعى) كه تغييرات هر يـارامتر

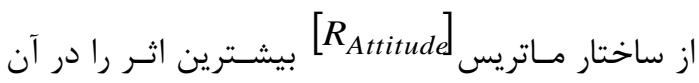

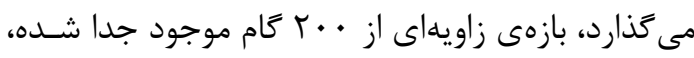

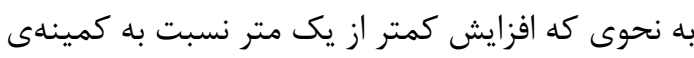

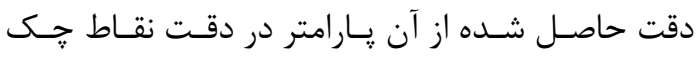

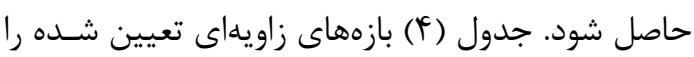

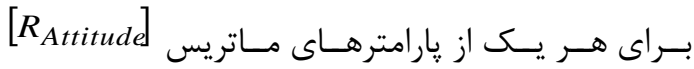
نشان مى دهد.

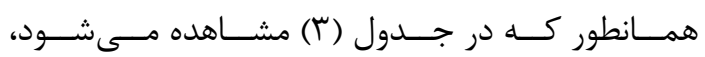

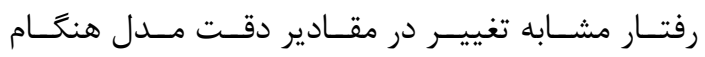
حضور تعمدى هر يك از يارامترها در سه مجموعه داده،

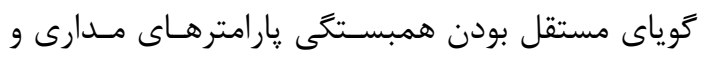

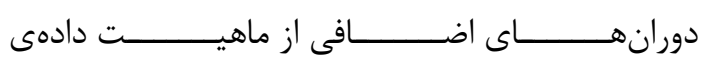

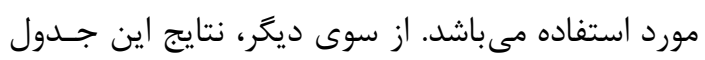

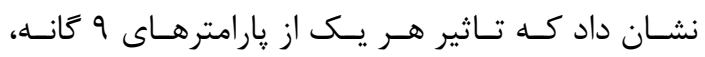

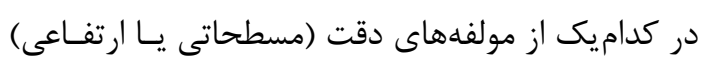

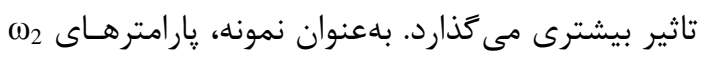

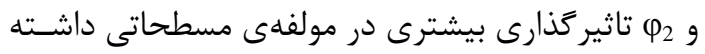

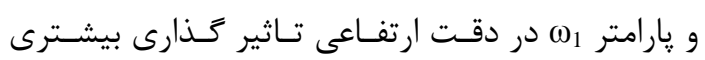

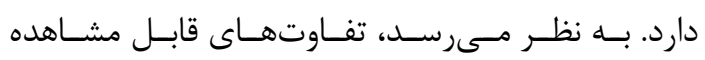

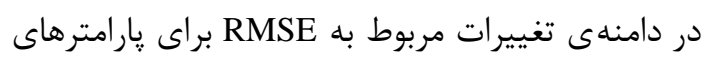

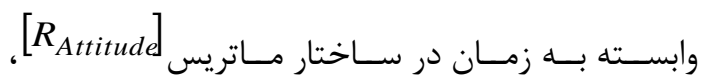

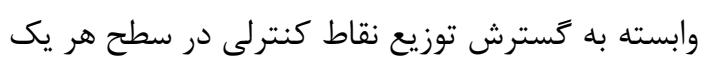

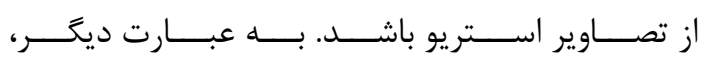

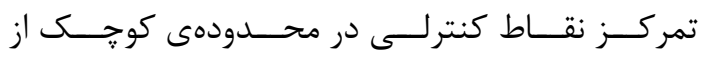
سطرهاى صحنه (مولفهى در راستاى حركت سنجنده)،

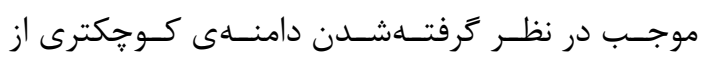

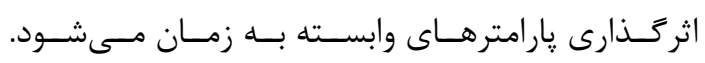

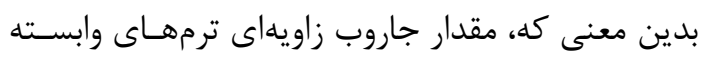

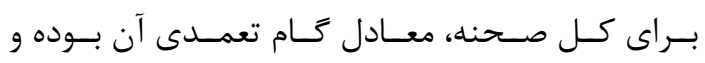

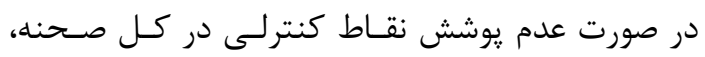

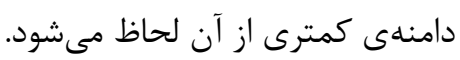

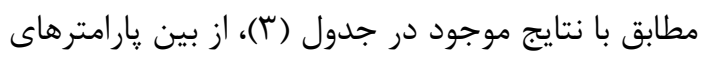

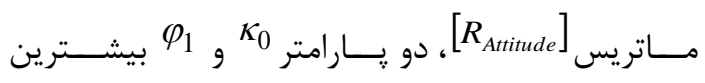

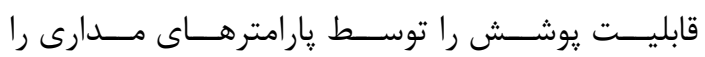

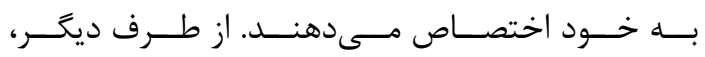
جدول F: دامنهى زاويهاى يارامترهاى ماتريس RAttitude كه بدون تاثير فاحش در دقت، اثر آن توسط مدل مدارى صلب قابل يوشش مى باشد

\begin{tabular}{|c|c|c|c|c|c|c|c|c|}
\hline$\omega_{0}$ & $\omega_{1}$ & $\omega_{2}$ & $\varphi_{\mathrm{o}}$ & $\varphi_{1}$ & $\varphi_{2}$ & $\kappa_{\mathrm{o}}$ & $\kappa_{1}$ & $\kappa_{2}$ \\
\hline$-0.53^{\circ} \sim 0.65^{\circ}$ & $-0.05^{\circ} \sim 0.05^{\circ}$ & $-0.01^{\circ} \sim 0.01^{\circ}$ & $-1.91^{\circ} \sim 3^{\circ}$ & $-3^{\circ} \sim 3^{\circ}$ & $-0.011^{\circ} \sim 0.01^{\circ}$ & $-3^{\circ} \sim 3^{\circ}$ & $-0.2^{\circ} \sim 0.14^{\circ}$ & $-0.14^{\circ} \sim 0.56^{\circ}$ \\
\hline
\end{tabular}

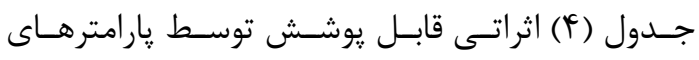

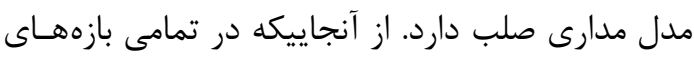

انتخـاب مقـادير تصـادفى بــراى بارامترهـاى 9 كانــى

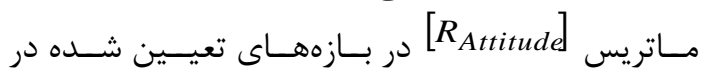




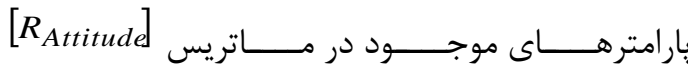

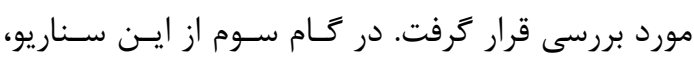

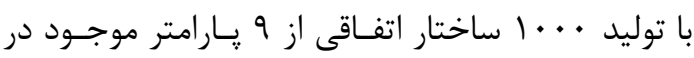

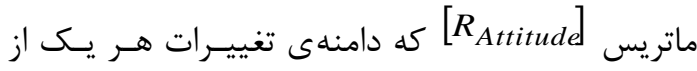

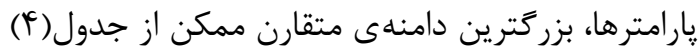

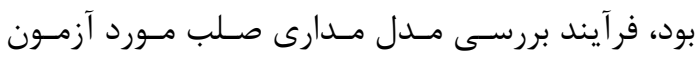

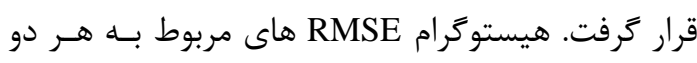

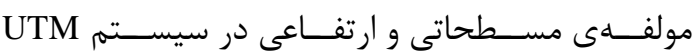

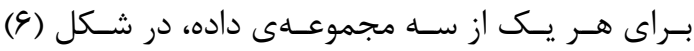
نشان داده شدهاست.
فــوق مسىــــان مقــدار صـفر را اختيـار نمـود، بنـابراين

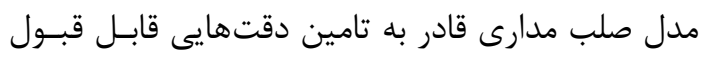

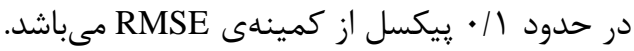

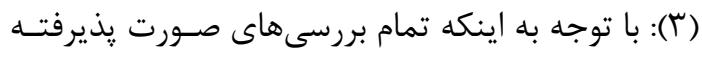

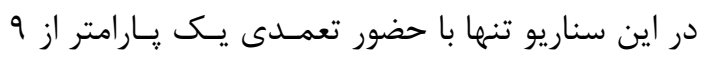

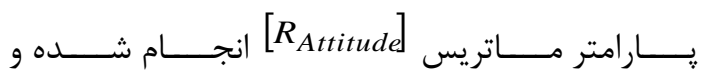

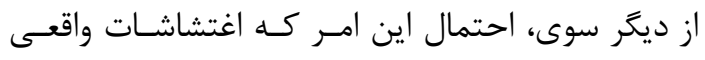

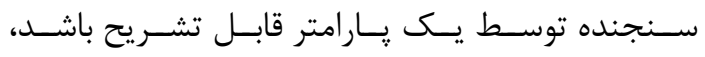

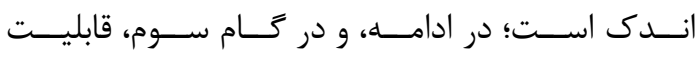

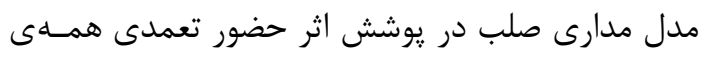

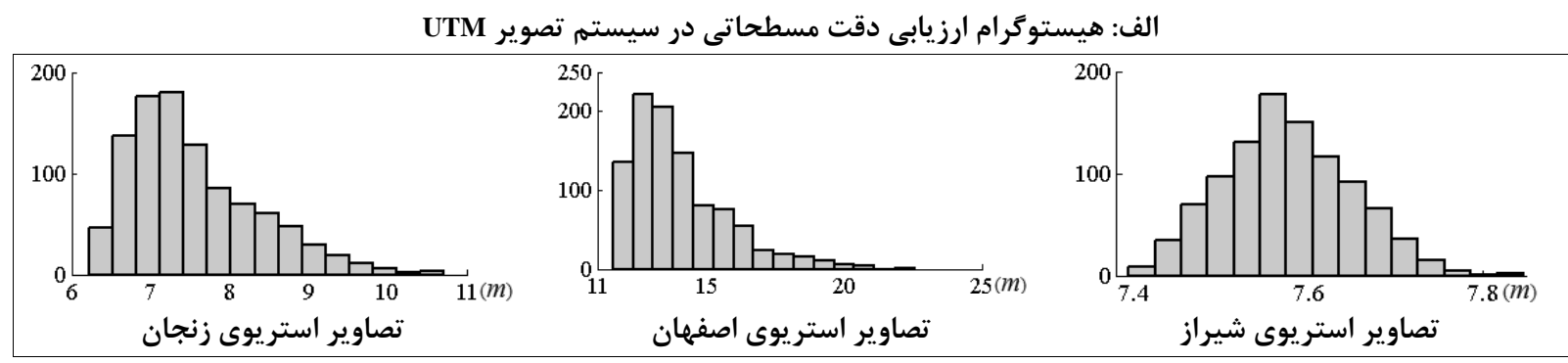

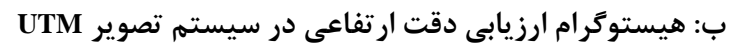

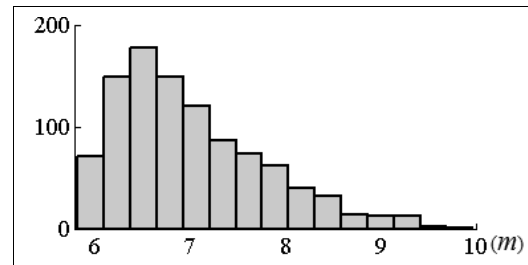

تصاوير استريوى زنجان

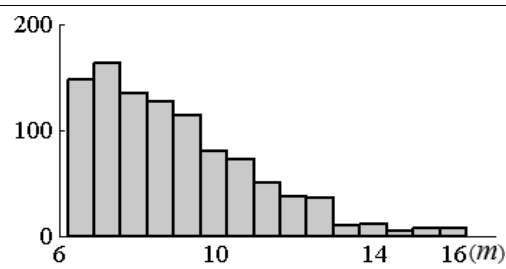

تصاوير استريوى اصفهان

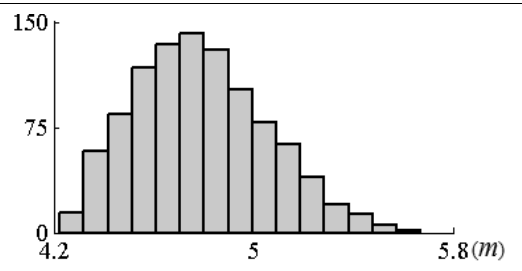

تصاوير استريوى شيراز

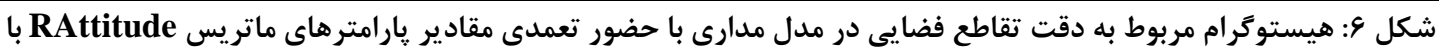

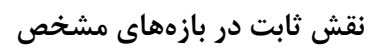

در نقاط جك، دقت قابل قبولى تامين گردد.

ץ-ץ-بررسى حساسيت تخمين پارامتر هاى مـدل

صلب به تعداد نقاط كنترلى

با توجه به اثبـات وجـود همبسـتختى ميـان پارامترهـاى

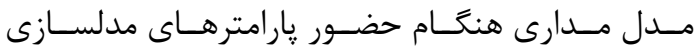

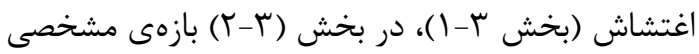

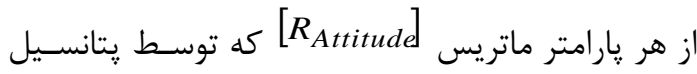

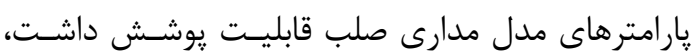

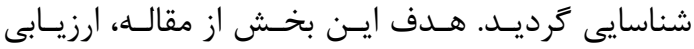

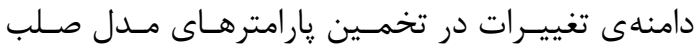

رفتار هيستو گرامهاى موجود در شكل(థ) گوياى تمركز

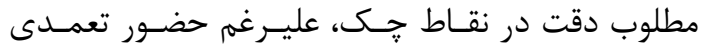

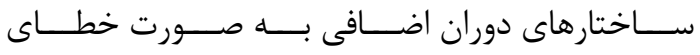
سيستماتيك در مدل (O.P.M) و حل دستگاه معادلات تنها با مجهول در نظر كرفتن تنها شش يارامتر مـدارى

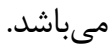
نتايج ايـن ســاريو حـاكى از همبســتخى نسـبى ميـان

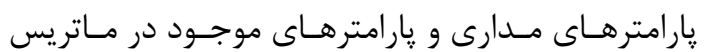

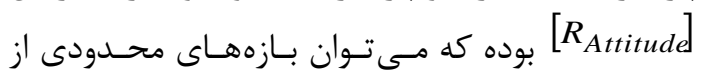
اغتشاشات وضعيتى را به كمك مدل صلب يوشـش داد باد به نحوى كه بدون تاثير فاحش در سـطح دقـت بـرازش 
فضـاى جــوابهــاى ممكـن بــراى دسـتـاه معـادلات و همجنين حساسيت تخمين پارامترهاى مدل به تعداد و

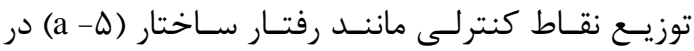
جدول(Y)، احتمال وجود همبسـتخىى بـين زارامترهـاى مدل صلب قوّت مى گيرد. جدول (و) دامنـهى تغييـرات

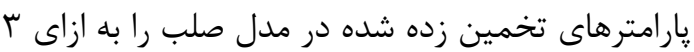

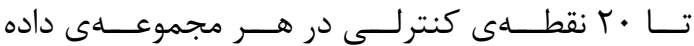

نشان مى دهد.

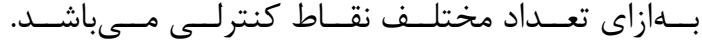

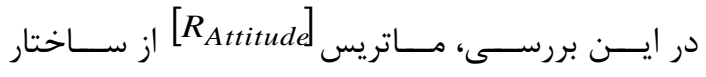

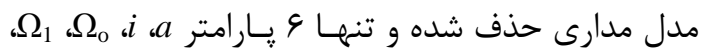

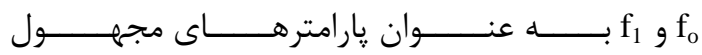
در نظر گرفته شدهاند. استدلال انجام اين كار را مى لَّوان بررسى همبسـتخَى گارامترهـاى مـدل صـلب مـدارى و

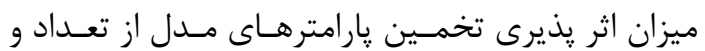

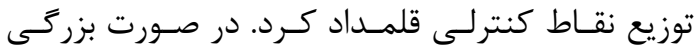

جدول \&: دامنهى تغييرات تخمين هارامترهاى مدل مدارى صلب به ازاى تعداد مختلف نقاط كنترلى

\begin{tabular}{|c|c|c|c|c|c|c|c|}
\hline Datasets & imeters & $\begin{array}{c}a \\
(m)\end{array}$ & $\begin{array}{c}I \\
(D e g)\end{array}$ & $\begin{array}{c}\mathbf{f}_{\mathbf{o}} \\
(\text { Deg })\end{array}$ & $\begin{array}{c}\Omega_{0} \\
(\text { Deg })\end{array}$ & $\begin{array}{c}\mathbf{f}_{1} \\
(\text { Deg/Line })\end{array}$ & $\begin{array}{c}\mathbf{\Omega}_{1} \\
(\text { Deg/Line })\end{array}$ \\
\hline \multirow{2}{*}{ زنجان } & تصوير اول & 181.55 & 0.01 & $2.3 \mathrm{E}-03$ & $1.0 \mathrm{E}-02$ & $4.2 \mathrm{E}-08$ & $3.2 \mathrm{E}-08$ \\
\hline & تصوير دوم & 356.71 & 0.03 & $1.7 \mathrm{E}-03$ & $2.0 \mathrm{E}-02$ & $3.0 \mathrm{E}-08$ & 7.0E-08 \\
\hline \multirow{2}{*}{ اصفهان } & تصوير اول & 384.05 & 0.01 & $1.1 \mathrm{E}-03$ & $4.6 \mathrm{E}-03$ & $2.0 \mathrm{E}-08$ & $5.0 \mathrm{E}-08$ \\
\hline & تصوير دوم & 323.36 & 0.02 & 8.5E-04 & 1.3E-02 & $3.2 \mathrm{E}-08$ & 6.3E-08 \\
\hline \multirow{2}{*}{ شيراز } & تصوير اول & 815.66 & 0.09 & $5.8 \mathrm{E}-03$ & $5.1 \mathrm{E}-02$ & $3.9 \mathrm{E}-07$ & 4.9E-07 \\
\hline & تصوير دوم & 724.12 & 0.10 & $1.3 \mathrm{E}-02$ & $6.0 \mathrm{E}-02$ & $4.5 \mathrm{E}-07$ & $4.9 \mathrm{E}-07$ \\
\hline
\end{tabular}

دستعاه معادلات افزوده نشده است.

ارزيابى دقت نتايج تقاطع فضايى در اين بررسى به ازاى

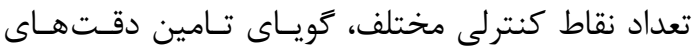

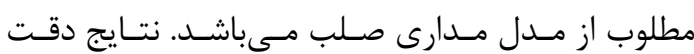

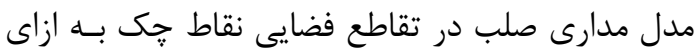
تعداد مختلفى از نقاط كنترلى براى هر مجموعهى داده
نتايج جدول (9) دامنهى تغييرات انـدكى را در مقايسـه

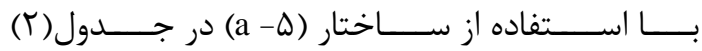
نشان مى دهد. وجود اين دامنهى اندك حساسيت نتايج تخمين پارامترهاى مدل صلب به تعـداد و توزيـع نقــاط كنترلـى را منتفـى مسىســازد. شـايان ذكـر اسـت كـهـ

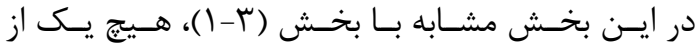

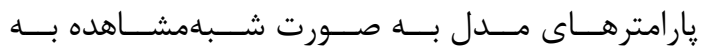

جدول \: دقت نتايج تقاطع فضايى در نقاط جك براى مدل مدارى صلب به ازاى تعداد مختلف نقاط كنترلى

\begin{tabular}{|c|c|c|c|c|}
\hline \multicolumn{2}{|c|}{ RMSE $(m)$} & \multicolumn{2}{|c|}{ GCPs } & \multirow{2}{*}{ مجموعهى داده } \\
\hline Orthometric & Planimetric & Check & Control & \\
\hline 7.09 & 6.88 & 28 & 3 & \multirow{5}{*}{ زنجان } \\
\hline 7.20 & 6.68 & 25 & 6 & \\
\hline 6.43 & 7.01 & 21 & 10 & \\
\hline 5.38 & 6.13 & 15 & 16 & \\
\hline 4.92 & 5.95 & 11 & 20 & \\
\hline 7.64 & 10.57 & 31 & 4 & \multirow{5}{*}{ اصفهان } \\
\hline 7.13 & 10.54 & 29 & 6 & \\
\hline 6.12 & 10.35 & 23 & 12 & \\
\hline 6.65 & 9.59 & 18 & 17 & \\
\hline 5.89 & 10.98 & 15 & 20 & \\
\hline 5.09 & 8.10 & 30 & 4 & \multirow{5}{*}{ شيراز } \\
\hline 4.96 & 8.15 & 28 & 6 & \\
\hline 4.79 & 7.36 & 22 & 12 & \\
\hline 4.75 & 7.40 & 17 & 17 & \\
\hline 5.22 & 7.59 & 14 & 20 & \\
\hline
\end{tabular}




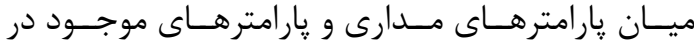

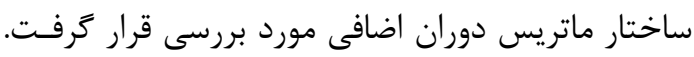

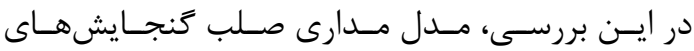

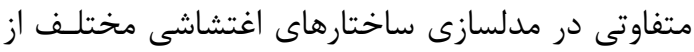

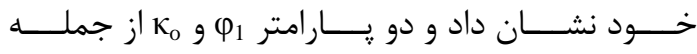
يارامترهايى بودند كه بيشترين سطح يوشش اثرات آنها توسط مدل مدارى صلب ممكن مىباشد.

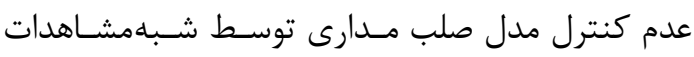

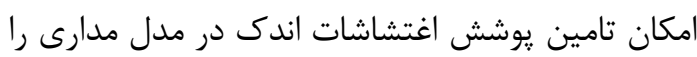

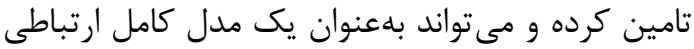

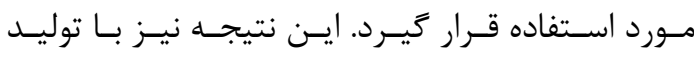

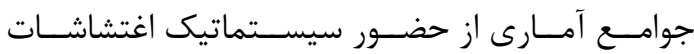

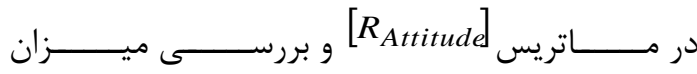
توفيق مدل مدارى در يوشـش اثـر اغتشاشـات مـذكور

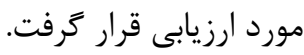

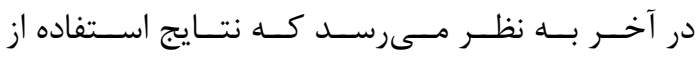
مــدل صـلب مـدارى در مـورد صـحنهـهـايى از تصـاوير

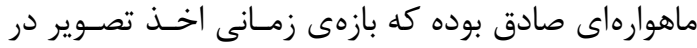

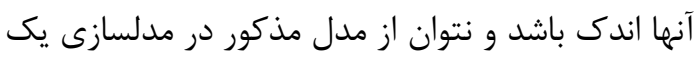

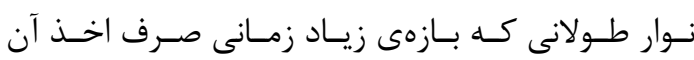
شده باشد، استفاده نمود؛ علت اين امـر را مسى تــوان در

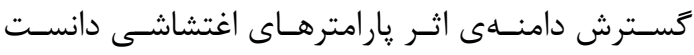

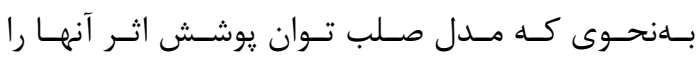

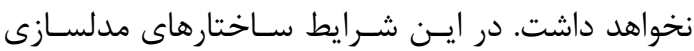

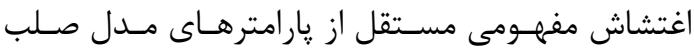

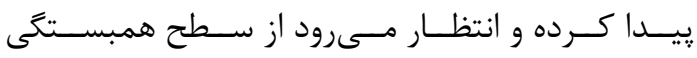

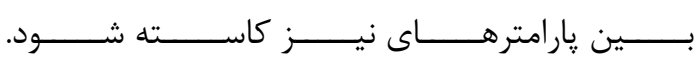
بررسى مـدل يارامترهـاى مـدارى بــدون لحـاظ كـردن

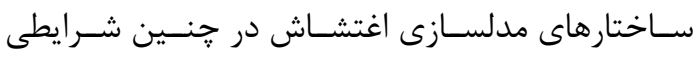
مى تواند بهعنوان افق تحقيقاتى ييش رو مطرح كردد.
با توجه به تامين دقت مطلوب در نتايج تقـاطع فضـايى نقاط جك (جدول V) و همجنين عدم حساسيت نتسايج

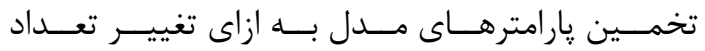
نقاط كنترلى، انتخاب مدل مــارى صــلب را بـه عنـــان

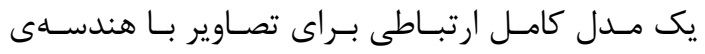

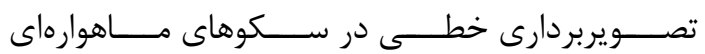

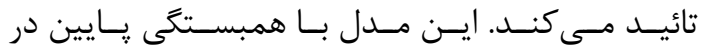
يارامترهاى خود، تنها با شش يـارامتر مجهـول شـرايط

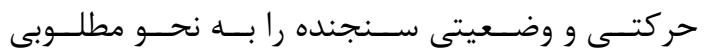

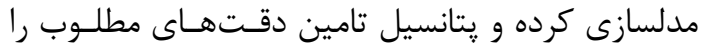

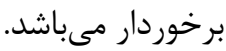

\section{F - بحث و نتيجه}

اين مقاله با هدف بررسى و تعيين سطح همبستخى بين

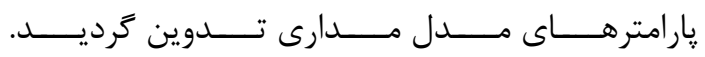
ضرورت اين بررسى را مى توان در شناسايى پارامترهايى دانست كه اثر آنهـا توسـط سـاير پارامترهـا در سـاختار

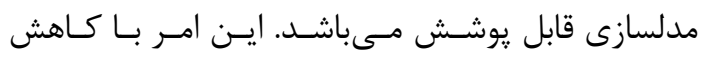

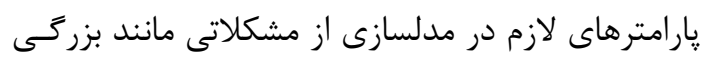

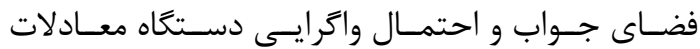

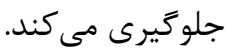

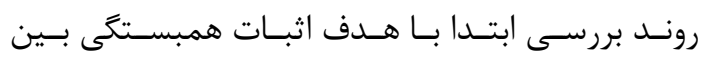

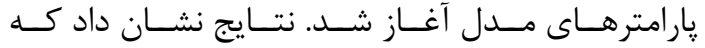

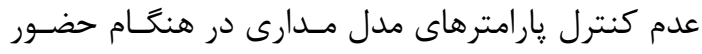

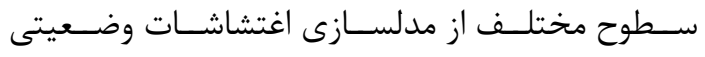

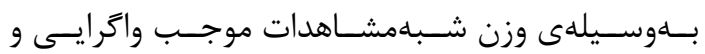

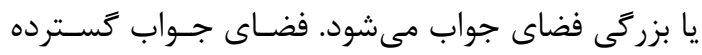

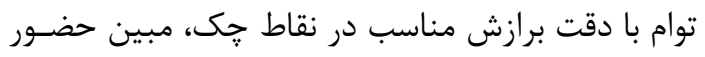

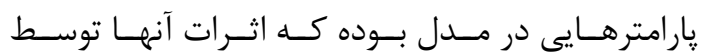

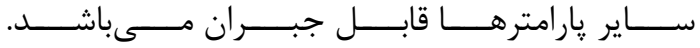

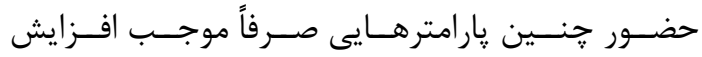

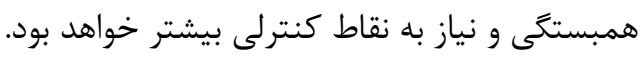

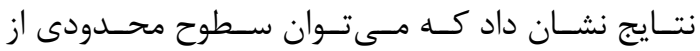

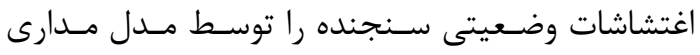

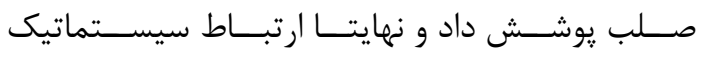


[1] Safdarinezhad, A. R., "Using Additional Parametres in Orbital Parameters Model for Improvement of Precision in Geometric Correction of Satellite Images," Msc Thesis, K. N. Toosi University of Technology, 2012. [2] Toutin, T, "Review Article: geometric processing of remote sensing images: models, algorithms and methods", International Journal of Remote Sensing, Vol. 25, pp. 1893-1924, 2004.

[3] Tao, C.V. and Hu, Y, "A comprehensive study of the rational function model photogrammetric processing.", Photogrammetric Engineeing and Remote Sensing, Vol. 67, pp. 1347-1357, 2001.

[4] Westin, T. 2, "Precision rectification of SPOT imagery," Photogrammetric Engineeing and Remote Sensing, Vol. 56, pp. 247-253, 1990. [5] Kim, T. and Dowman, I., "Comparsion of two physical sensor models for satellite images: Position-Rotation model and Orbit-Attitude Model.", Photogrammetric Record, Vol. 21, pp. 110-123, 2006.

[6] Konecny, G., Lohmann, P., Engel, H., Kruck, E., "Evaluation of SPOT imagery on analytical photogrammetric instruments.", Photogrammetric Engineering and Remote Sensing, Vol. 53 (9), pp. 1223-1230, 1987.

[7] Riazanoff, S., Gleyzes, J.P., Zobler, D., SPOT Satellite Geometry Handbook, GAEL Consultant, SPOT 123-4-5, 2004.

[8] Gugan, D., "Practical aspects of topographic mapping from SPOT imagery," Photogrammetric Record, Vol. 12, pp. 349-355, 1986.

[9] Safdarinezhad, A. and Valadan Zoej, M. J., "An optimized orbital parameters model for geometric correction of space images," Advances in Space Research, vol. 55, no. 5, pp. 1328-1338, 2015. DOI: $10.1016 /$ j.asr.2014.12.018.

[10] Radhadevi, P.V., "Pass processing of IRS1C/1D PAN subscene blocks," ISPRS Journal of Photogrammetry and Remote Sensing, pp. 289297, 1999.

[11] Salamonowicz, P.H., "Satellite orientation and position for geometric correction of scanner imagery," Photogrammetric Engineeing and Remote Sensing, pp. 491-499, 1986.

[12] Valadan Zoej, M.J., Sadeghian, S., "Orbital parameter modeling accuracy testing of Ikonos Geo image," Photogramm. J. Finland, Vol. 18, pp. 70-80, 2003.

[13] Seeber, G., Satellite Geodesy. 2nd Edition.
New York : DeGruyter, 2003.

[14] Wertz, J.R., Spacecraft Attitude Determination and Control. Dordrecht : Reidel, 1978. 


\title{
Investigation level of correlation between orbital parameters model for geometric correction of satellite imagery
}

Alireza Safdari Nezhad ${ }^{1 *}$, Mohammd Javad Valadan Zoej ${ }^{2}$, Mehdi Mokhtarzade $^{3}$

1 Phd student of remote sensing in Department of Geomatics, KN.Toosi University of technology

2 Associate professor in Department of Geomatics, KN.Toosi University of technology

3 Associate professor in Department of Geomatics, KN.Toosi University of technology

\begin{abstract}
Orbital parameters model is one of the fully constrained physical models for geometrical correction of satellite imagery. The model has been developed to cover the physical conditions prevailing in the acquisition period of satellite platforms. The multiplicity of parameters in the modeling and correlation between them causes difficulties in solving the system of equations. Generally, problems are greatly reduced by adding the model parameters in the form of quasi observations and controlling trend of corrections by the values of each parameter's weights. However, it is difficult to determine the correct values of quasi observations' weight due to the approximate precision of auxiliary data. Furthermore wrong weights of quasi observations impose additional parameters in the model structure. In this article, by providing some scenarios, the level of correlations between orbital model parameters and also the capability of rigid orbital model in the covering effect of perturbations are evaluated. The obtained results proved that unconsidered perturbations, occurring in a specified domain, are coverable by other correlated parameters of rigid orbital parameters model. This ability of the rigid orbital parameters model is more evident when quasi observations are not applied in the model.
\end{abstract}

Key words: Orbital Parameters Model, Correlation, Space Intersection, Colinearity Equation, Keplerian Parameters, Satellite Imagery.

Correspondence Address: Alireza Safdari Nezhad: Remote Sensing Group, Department of Geomatics, K.N. Toosi Universty of technology, Tehran, Iran.

Tel: +98 9123258852. Email: Safdari_Nezhad@sina.kntu.ac.ir 